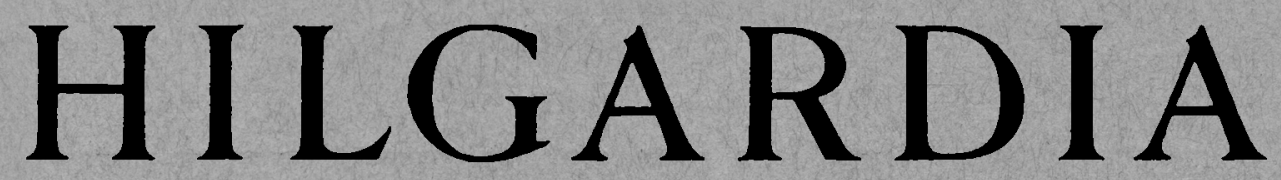

A Journal of Agricultural Science Published by the California Agricultural Experiment Station

RESPONSES OF THE RICE PLANT TO DIFFERENT FORMULATIONS AND METHODS OF APPLICATION OF 2,4-D, MCP, and 2,4,5-T

P. B. KAUFMAN and A. S. CRAFTS 
The research described in this paper is a continuation of studies carried on during the past four years on the effects of the phenoxyacetic acid herbicides cn rice and on weeds of rice fields. Injury to rice from 2,4-D sprays is fairly con:mion; injury to surrounding sensitive crops from spray drift has also been experienced. The study described here compared the effects on rice and on weeds of 2,4-D, MCP, and 2,4,5-T applied to the water on rice cultures and applied as pellets to rice cultures. Applied to the water in aqueous solution, the most deleterious effects on the rice plants occurred when the rice seed was sown on top of the soil, as contrasted with being drilled into the soil; when the rice was treated at early stages of growth; when dosage was high; and when 2,4-D was used. Treatments with pellets caused intense aberrations in rice and aquatic weeds when plants were young, when desage was high, and when 2,4-D was used. MCP was less injurious to rice, yet it killed aquatic weeds. The 2,4,5-T treatments were ineffective against weeds. At equivalent dosage, pellets were more selective than were aqueous solutions. Pellets effectively controlled aquatic weeds in rice wishout injury to the latter under greenhouse conditions. 


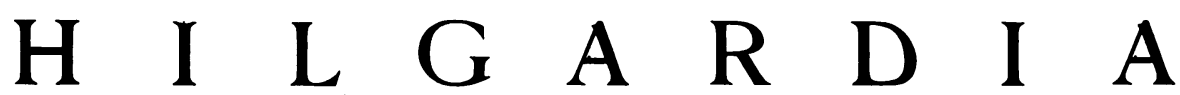

A Journal of Agricultural Science Published by

the California Agricultural Experiment Station

VoL. 24

APRIL, 1956

No. 15

\section{RESPONSES OF THE RICE PLANT TO DIFFERENT FORMU- LATIONS AND METHODS OF APPLICATION OF 2,4-D, MCP, AND 2,4,5-T ${ }^{1,2}$}

\section{P. B. KAUfMAN ${ }^{3}$ and A. S. CRAFTS}

\section{INTRODUCTION}

AERial application of 2,4-D and related compounds for control of aquatic weeds in rice fields has created a serious problem with respect to drift of the herbicides to adjacent susceptible crops. Because current practices do not entirely eliminate herbicidal drift, new methods of application are being sought. One suggested method is the aerial application of pelleted formulations of various agricultural chemicals. Another approach involves introducing the herbicide into water that flows into the rice field. The present paper describes experiments on these two methods of application.

The present investigation had two main objectives: (1) to determine the response of drilled and sown rice, treated at different stages of development, to foliar and water applications of aqueous solutions of several formulations and dosages of 2,4-D, MCP, and 2,4,5-T; and (2) to determine the response of rice and several aquatic weeds, at various stages of development, to water applications of certain formulations and dosages of pelleted 2,4-D, MCP, and $2,4,5-\mathrm{T}$. The primary question was whether pelleted formulations of these growth regulators would be sufficiently selective through the water to avoid injuring the rice and yet toxic enough to control effectively some of the major aquatic weeds found in rice fields.

\section{PROCEDURE}

Experiment with Aqueous Solutions and Small-can Cultures of Rice. Onegallon cans were filled with Yolo clay loam to a depth of about 5.25 inches, leaving 1.25 inches for free water and 0.5 inch free space at the top. Caloro

\footnotetext{
${ }^{1}$ Received for publication June 8, 1955.

${ }^{2}$ Experiments were conducted in the greenhouses of the Department of Botany at Davis by Mr. Bud Adamson and Mr. Tyler Nakashima under the supervision of Professor Crafts and Dr. Kaufman. The work was supported by a grant from the Chipman Chemical Company.

${ }^{3}$ Teaching Assistant in Botany, Davis (resigned June 30, 1954).

${ }^{4}$ Professor of Botany and Botanist in the Experiment Station, Davis.
} 
variety of rice, harvested in 1953, was presoaked for two days, then planted in the cans as follows: (1) drilled into the soil approximately 0.5 inch deep; and (2) sown on the soil surface. The water level was then raised to 0.5 inch from the tops of the cans, and maintained at that height for the duration of the experiment. Two replications were included for each of the treatments.

Rice cultures were treated at three different periods as indicated in table 1.

TABLE 1

METHODS OF APPLICATION OF 2,4-D, MCP, AND 2,4,5-T, AND STATES OF DEVELOPMENT OF RICE AT VARIOUS TREATMENT DATES

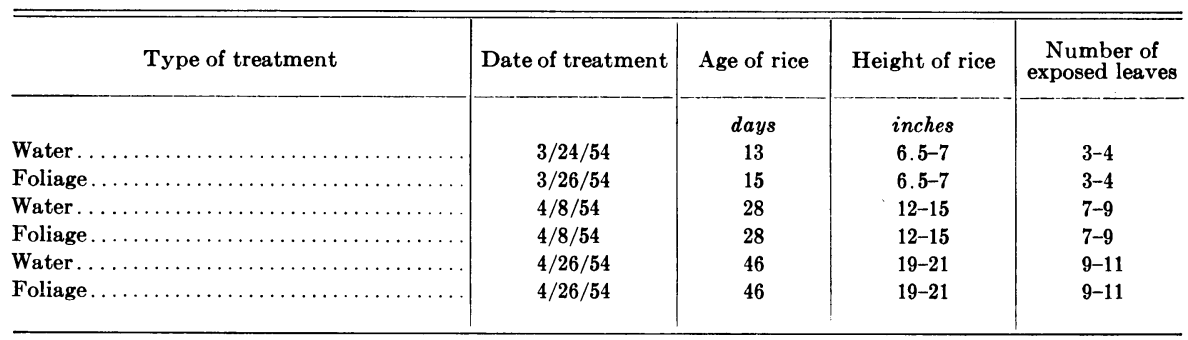

The chemicals employed included 2,4-D (triethanolamine salt), MCP (triethanolamine and sodium salts), and 2,4,5-T (triethanolamine salt). These were applied at rates of $1.5,3,6$, and 12 pounds acid equivalent per acre, as aqueous solutions. In water applications, a $20-\mathrm{ml}$ aliquot was placed directly in the water surrounding the rice plants; in foliar applications, a 20-ml aliquot was applied to the leaves with a pressurized hand sprayer. (The cultures were rotated on a turntable.)

Data obtained included qualitative assessment of various symptoms (see pp. 440-453) shown by treated plants, measurement of heights of plants, and determination of dry weights of mature shoots (minus panicles) and the number and dry weight of panicles per culture.

Experiment with Pelleted Formulations and Large-can Cultures of Rice and Aquatic Weeds. Five-gallon cans were filled with Sacramento clay loam to a depth of about 7.8 inches, leaving 4.0 to 4.5 inches for free water and about 1 inch free space at the top. The rice was treated as mentioned above, and sown on the soil surface. The water level was then raised to 0.5 inch above the soil surface. After seed germination, seedlings were thinned to approximately 15 , and redistributed uniformly by transplanting.

A weed-seed mixture, composed of watergrass (Echinochloa Crusgalli), water plantain (Alisma Plantago), redstem (Ammania coccinea), and cattail (Typha latifolia), was sown into the rice cultures six days after the rice was planted. Two arrowhead tubers (Sagittaria sp.) were planted in each culture, at a depth of around 0.5 inch, on the same date.

Rice cultures were treated at three different periods as indicated in table 2.

At the time of each treatment, the water level was raised to about 1 inch from the rims of the cans, and retained at that height until termination of the experiment.

The chemicals employed included 2,4-D (triethanolamine salt), MCP (triethanolamine, sodium, and potassium salts and butyl ester), and 2,4,5-T 
(propyleneglycolbutylether ester). Each of these materials was formulated as pellets ${ }^{5}$ of $15 / 30$ and 30/60 mesh. Amounts of material applied included $1.5,3$, and 6 pounds acid equivalent per acre. Both mesh sizes were used for the first two treatment periods, and the 15/30 mesh for the third.

In making an herbicidal application, a cylinder of cardboard was placed in the can, surrounding the rice plants and weeds, to insure inclusion of all the pellets within the culture. Pellets were applied manually and uniformly

TABLE 2

METHOD OF A,PPLICATION OF 2,4-D, MCP, AND 2,4,5-T, AND STAGES OF DEVELOPMENT OF RICE AND AQUATIC WEEDS AT VARIOUS TREATMENT DATES

\begin{tabular}{c|c|c|c|c|c|c}
\hline \multicolumn{1}{c}{ Type of treatment } & $\begin{array}{c}\text { Date of } \\
\text { treatment }\end{array}$ & $\begin{array}{c}\text { Age of } \\
\text { rice }\end{array}$ & $\begin{array}{c}\text { Height of } \\
\text { rice }\end{array}$ & $\begin{array}{c}\text { Number of } \\
\text { exposed } \\
\text { leaves }\end{array}$ & $\begin{array}{l}\text { Weeds that } \\
\text { germinated }\end{array}$ & $\begin{array}{c}\text { Height of } \\
\text { weeds }\end{array}$ \\
\hline Pellets in water......... & $4 / 19 / 54$ & 31 & $13-15$ & $7-9$ & $\begin{array}{l}\text { Arrowhead } \\
\text { Redstem } \\
\text { Water plantain }\end{array}$ & $\begin{array}{c}\text { inches } \\
13-15 \\
0.5-1 \\
0.0^{*}\end{array}$ \\
Pellets in water......... & $4 / 27 / 54$ & 39 & $15-18$ & $9-10$ & $\begin{array}{l}\text { Arrowhead } \\
\text { Redstem } \\
\text { Water plantain }\end{array}$ & $\begin{array}{c}15-18 \\
3-4 \\
1\end{array}$ \\
Pellets in water.......... & $5 / 18 / 54$ & 60 & $18-20$ & $9-10$ & $\begin{array}{l}\text { Arrowhead } \\
\text { Redstem } \\
\text { Water plantain }\end{array}$ & $5-6$ \\
\hline
\end{tabular}

* Water plantain had not germinated at this time.

to the water at a short distance above the highest leaves (to simulate an airplane application).

Data obtained were the same as mentioned above.

\section{RESULTS OF EXPERIMENTS WITH AQUEOUS SOLUTIONS OF GROWTH REGULATOR AND SMALL-CAN CULTURES OF RICE}

Data obtained from these experiments are summarized in tables 3 to 6 (pages 440-447). This information is tabulated in such a manner that interaction of the various factors studied can be ascertained. The results of the several experiments described below are primarily based upon these data.

\section{Effect of Method of Planting}

In commercial rice fields of the United States, seed is usually planted by drilling with ground machinery or sowing by airplane. It was believed that this difference in planting method might account for some of the differences in response of rice to water applications of growth regulator herbicides, especially in connection with younger stages of development. Thus, in each of the treatments, rice grains were sown on the soil surface or drilled into the soil to a depth of about $1 / 2$ inch.

\footnotetext{
${ }^{5}$ Active ingredients were impregnated on Attaclay.
} 
Criteria for assessing relative responses of rice to the two methods of planting included qualitative observations (see aberration indices, tables 3 to 6 ), average shoot height, dry weight per shoot, number of panicles per plant, and dry weight per panicle. Height and fresh weight data have been used consistently with reliability by Crafts $(1935)^{6}$ in numerous soil sterilant bioassays. Of the indices listed above, number of panicles proved to be so variable that no significance could be attached to this factor, and the results presented below are based only on the other criteria.

In comparing the data in tables 3 to 6 , the following responses can be noted: (1) The greatest expression of aberrations occurred consistently in treated cultures in which the rice was sown on the soil surface. (2) This was most strikingly demonstrated in the earliest applications (13 days after planting) where the growth regulator was applied to the water at the highest dosage levels. (3) The time of application proved to be highly critical, for there was a successive diminution in differences between sown and drilled cultures from 13 to 28 to 46 days. (4) In comparing foliage with water treatments, no significant differences could be found between sown and drilled cultures in most of the foliage applications, while the reverse was true in the water applications.

Differences in response of sown and drilled rice to applications of 2,4-D and MCP are shown in figures 1 and 2, respectively. In the graph (fig. 1), the three indices-height of shoots, dry weight per shoot, and dry weight per panicle-collectively support the contention that rice plants exhibit more pronounced growth regulator-induced aberrations when the grains are sown than when they are drilled.

Figure 2 also illustrates the greater expression of morphological aberrations in MCP-treated cultures where rice is sown. Reduction in density of initial rice population and diminution in height of shoots are greatest in culture 2 (rice sown); contrast this with culture 3 (rice drilled).

\section{Age of Rice Plants in Relation to Time of Application of Growth Regulator}

During its vegetative phase of development (seedling through tillering to boot stages), the rice plant expresses aberrations of much greater intensity when growth regulator treatments are made during early stages (seedling to pretillering) (Kaufman, 1953). This has been demonstrated conclusively in controlled greenhouse tests and field experiments. Heretofore, these observations were based only upon foliar applications of 2,4-D, MCP, and 2,4,5-T. Obviously, it was of interest to learn whether this phenomenon also held true for water applications.

Data in tables 3 to 6 and figures 3 to 6 show several responses which are in agreement with previous findings (Kaufman, 1953): (1) There is a perceptible diminution in intensity of growth aberrations when applications (water only) are made at successively later stages of development (13, 28, and 46 days, respectively). (2) These aberrations are expressed to the greatest extent where seed was sown and the growth regulator applied to water at the highest dosage level (12 pounds acid equivalent per acre) on the

\footnotetext{
"See "Literature Cited" for citations referred to in the text by author and date.
} 
first date of application (13 days after planting). (3) A slight but consistent stimulatory effect, in terms of increase in height of shoots, weight per shoot, and weight per panicle, was detectable in water-treated cultures where applications were made at the second stage of development ( 28 days). (Figs. 3, 6.) (4) In the foliage applications, the effect noted after (1) above was not clearly apparent except in the 2,4-D treatments (compare fig. 4A with $5 \mathrm{~A})$. This can probably be attributed to the relatively low dosages employed in the foliage applications, i.e., 1.5 and 3 pounds acid equivalent per acre.

\section{Influence of Method of Application}

In earlier experiments (Kaufman, 1953), evidence was presented on the response of rice to direct foliage applications of 2,4-D as contrasted with treatments made only to water surrounding the plants. There was some indication that more intense aberrations resulted from the water treatments. Since method of application was an important factor in the present experiments, water and foliage applications were included in all of the treatments.

Data in tables 3 to 6 and figures 4,5 , and 7 reveal several interesting responses of rice to foliar and water applications: (1) In contrast to foliar applications, water applications showed significant but not always consistent augmentation in intensity of aberrant growth responses. (2) This is most apparent in the early applications (13 days after planting) of 2,4-D and MCP at the 3-pound dosage in cultures where rice is sown. (3) It is doubtful if any significant differences exist in the 2,4,5-T treatments and in most of the treatments (with all growth regulators) made during later stages of development (28 and 46 days after planting). (4) In the foliage applications, there is a growth stimulatory effect with respect to height, weight per shoot, and weight per panicle (fig. 7 ) at the lowest dosage (1.5 pounds acid equivalent per acre) of growth regulator applied.

\section{Response of Rice to Several Growth Regulators Applied at Various Dosages}

In previous investigations on rice, conducted in the greenhouse and the field, it was clear that MCP usually was more selective (caused less injury to rice) than 2,4-D and that morphological aberrations induced by 2,4,5-T were negligible except when rice was treated at early stages of development. On the basis of empirical field observations, there was also some indication that sodium MCP was more selective than amine MCP. Furthermore, few differences in morphological response due to variations in dosage (range 15 to 25 ounces acid equivalent per acre) of 2,4-D, MCP, and 2,4,5-T (amine salts), were observed in the greenhouse tests. With this information in mind, we added sodium MCP and expanded the concentration range (see Procedure, p. 411) for each of the chemicals tested.

Tables 3 to 7 and figures 1, 3, 8, and 9 show the following responses to the various growth regulators and dosages: (1) The most intense abberations, with few exceptions (fig. 8), were found in the 2,4-D treatments, particularly in the water applications to sown rice that was treated with the highest dosage at the earliest stage of development. (2) Aberrations of 
intermediate intensity occurred in most of the MCP treatments, with no significant differences between the sodium and amine salt formulations. (3) 2,4,5-T induced few or no aberrations except at the earliest application date where injury was far less striking than in the 2,4-D and MCP treatments. (4) Within the dosage range of 1.5 to 12 pounds acid equivalent per acre, it was obvious that the intensity of injury to rice was progressively greater with increase in dosage (figs. 8 and 9 ) in the first and second treatments, and that such differences were not expressed in the third treatment (46 days after planting).

\section{RESULTS OF EXPERIMENTS WITH PELLETED FORMULA- TIONS AND LARGE-CAN CULTURES OF RICE AND AQUATIC WEEDS}

The data obtained in this series of experiments are assembled in tables 7 to 9 (pages 448-453). Reference should be made to these tables to assess the interaction of the various factors studied and to secure complete information pertaining to interpretations made in the following sections.

\section{Age of Rice Plants in Relation to Time of Application}

Pelleted formulations of 2,4-D, MCP, and 2,4,5-T were applied to water in cultures of rice and several aquatic weeds on three different dates. (See table 2, p. 413), for dates of application and corresponding stages of development of rice and aquatic weeds.) The primary objective of these timesequence experiments was to determine the sensitivity of rice and aquatic weeds, at several stages of development, to pelleted formulations of several growth regulators. We had observed a rather striking trend in the experiments with aqueous solutions applied to the water (see p. 414). The question was whether this same phenomenon would become evident with pelleted formulations.

The aberration indices and data on growth in tables 7 to 9 , and the graph in figure 9 disclose several significant responses of rice to the time-sequence treatments. The time of application-stage of development response, so evident in experiments with foliar and water treatments with aqueous solutions, is not so clearly demonstrated in experiments with pelleted formulations. In spite of several exceptions, there was a subtle diminution in injury to rice at successively later application dates of the 6-pound dosage. (Compare the various treatments at the 6-pound dosage with controls at different application dates in tables 7 to 9.) The 2,4,5-T and butyl ester MCP treatments are the most apparent exceptions to this generalization. Within the first application series (31 days after planting), at the 6-pound dosage, growth of rice plants, in terms of height of shoots, weight per shoot, and weight per panicle, was usually less than in control cultures (fig. 9). However, in later applications (39 and 60 days after planting), growth of treated plants approached that of the controls. This is also reflected indirectly in the aberration indices for rice in tables 7 to 9 . At dosages of 1.5 and 3 pounds acid equivalent per acre, there was, rather consistently, a striking growth stimulatory response with MCP and 2,4-D treatments. It should be emphasized that the formative effects due to these treatments, as expressed 
in the herbicidal indices for rice, were observed at periods preceding the harvest by several weeks. The growth stimulatory responses are exemplified by harvest data obtained at the conclusion of the experiment. It is possible to have growth aberrations (e.g., tubular leaves, swollen shoot bases) concurrent with general augmentation of shoot growth. The stimulation of growth was most pronounced in the first application treatment, and diminished in successively later applications (fig. 9). (See Discussion, p. 432, for possible explanation of this effect.)

\section{Response of Rice to Different Growth Regulators Applied at Several Dosages}

With respect to the different chemicals used, it was diffieult to discern any significant differences in intensity of injury to rice, primarily because deleterious effects exhibited by treated plants were not striking in the large-can cultures. (Compare aberration indices for rice in treatments with aqueous solutions with treatments where pelleted formulations were used, tables 3 to 9$)$. Nevertheless, subtle trends were evident. Most of the growth regulators evoked a growth stimulatory response in cultures treated with dosages of 1.5 and 3 pounds acid equivalent per acre (tables 7 to 9 , fig. 10). This effect was most pronounced in treatments with the various salts of MCP, and least evident with amine 2,4-D (fig. 10). At the 6-pound dosage, growth inhibitory responses were induced by most of the treatments, a notable exception being the ester formulation of 2,4,5-T. Wide variation in degree of growth inhibition with the various salts of MCP at this dosage does not permit any generalization on possible significant differences between these formulations. Within the limits of variation noted between 2,4-D and MCP treatments, the inhibitory responses are grossly similar. It is doubtful whether any significant differences could be obtained from comparison of 2,4-D treatments with similar treatments of any one of the MCP salts. It is important to reiterate the significance of the time of treatment-stage of development factor-namely, that a marked diminution in intensity of the above responses occurs with treatments made at successively later stages of development (31, 39, and 60 days after planting, respectively).

In considering the three dosages employed and the growth regulators, collectively, it was apparent, with a few exceptions, that within the first treatment series (31 days after planting), the order of injury to the rice, from most intense to least, was at 6,3 , and 1.5 pounds acid equivalent per acre. Injuries were less apparent in the second treatments (39 days after planting), and essentially negligible in the third series (60 days after planting). The least injury occurred with the 2,4,5-T treatments.

\section{Response of Rice to Two Pellet Sizes of Different Growth Regulators}

No significant differences were observed in intensity of injury to rice with the two pellet sizes (15/30 and 30/60 screen mesh). Discrepancies in growth responses were frequent when individual treatments with the two pellet sizes were compared (tables 7 to 9 ). However, because these data are so 
variable, no consistent trends could be established. On the basis of these observations, it is highly probable that pellet size is not an important factor influencing the response (growth stimulation or inhibition) of rice to growth regulator treatments.

\section{Responses of Various Aquatic Weeds ${ }^{7}$ to Different Growth Regulators}

The responses of aquatic weeds to pelleted formulations of the various growth regulators (tables 7 to 9 ) may be summarized as follows:

Effect of Treatment Time in Relation to Stage of Development. It was clearly demonstrated that redstem, water plantain, and arrowhead, at the stages treated, could be controlled with pelleted formulations of 2,4-D and MCP. Per cent control ${ }^{8}$ of these weeds was slightly greater after the first treatment (31 days after planting). However, satisfactory control of the above species was obtained at the 3 - and 6-pound dosages, with most of the formulations, after the last treatment (60 days after planting). Of all the growth regulators tested, only the 2,4,5-T failed to control weeds at the highest dosage ( 6 pounds acid equivalent per acre) in all three treatments.

Effect of Growth Regulators. It was obvious that the various salts and the butyl ester of MCP, and the triethanolamine salt of 2,4-D, effected more satisfactory weed control in most of the treatments than did the ester formulation of 2,4,5-T (tables 7 to 9 ; figs. 11, 12). In comparing MCP and 2,4-D, it appeared that they were about equally effective in controlling the aquatic weeds (compare fig. $12 \mathrm{~A}$ with $12 \mathrm{~B}$, culture 3 ). In some instances, at the 1.5- and 3-pound dosages, treatments with some salts of MCP resulted in slightly better control of weeds in the first and second treatment series than did comparable treatments with amine 2,4-D (tables 7 and 8). A comparison of the various salts of MCP showed that the potassium salt treatment (fig. $12 \mathrm{~A}$, culture 2 ; fig. 13 ) effected more complete control of the aquatic weeds than did the other MCP salts when results were examined for all three treatment periods. (Compare result for MCP salts in tables 7 to 9.) There were no significant differences in degree of aquatic weed control between the amine and sodium MCP treatments. All treatments failed to effect watergrass control. In general, aquatic weed control (with the exception of watergrass) was satisfactory with all of the growth regulators except 2,4,5-T, at most of the dosages employed, and at the stages of development of weeds designated for treatment (table 2, p. 413).

Effect of Pellet Size. No significant differences in intensity of injury to or control of aquatic weeds could be discerned in comparable treatments with the two pellet sizes. Pellet size was thus considered of little importance when compared with variations in type of growth regulator applied or time of application.

\footnotetext{
${ }^{7}$ Vegetative and flowering arrowhead (Sagittaria sp.) and watergrass (Echinochloa Crusgalli); seedlings of redstem (Ammania coccinea) and water plantain (Alisma Plantago). Cattail (Typha latifolia) failed to germinate. Weeds were grown with rice in largecan cultures.

${ }^{8}$ Control implies death of entire plant due to a particular growth regulator treatment.
} 


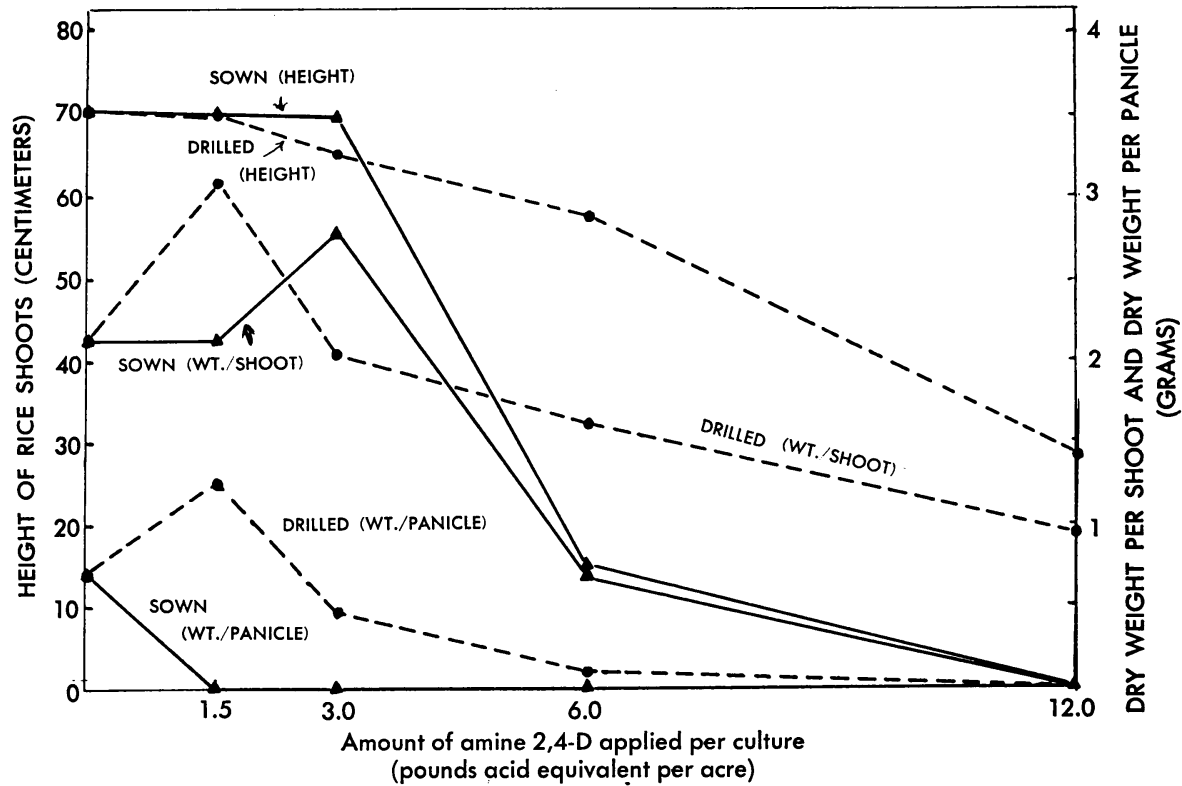

Fig. 1. Effect of drilling and sowing methods of planting on several growth responses of rice plants to four concentrations of amine 2,4-D applied to water 13 days after germination.

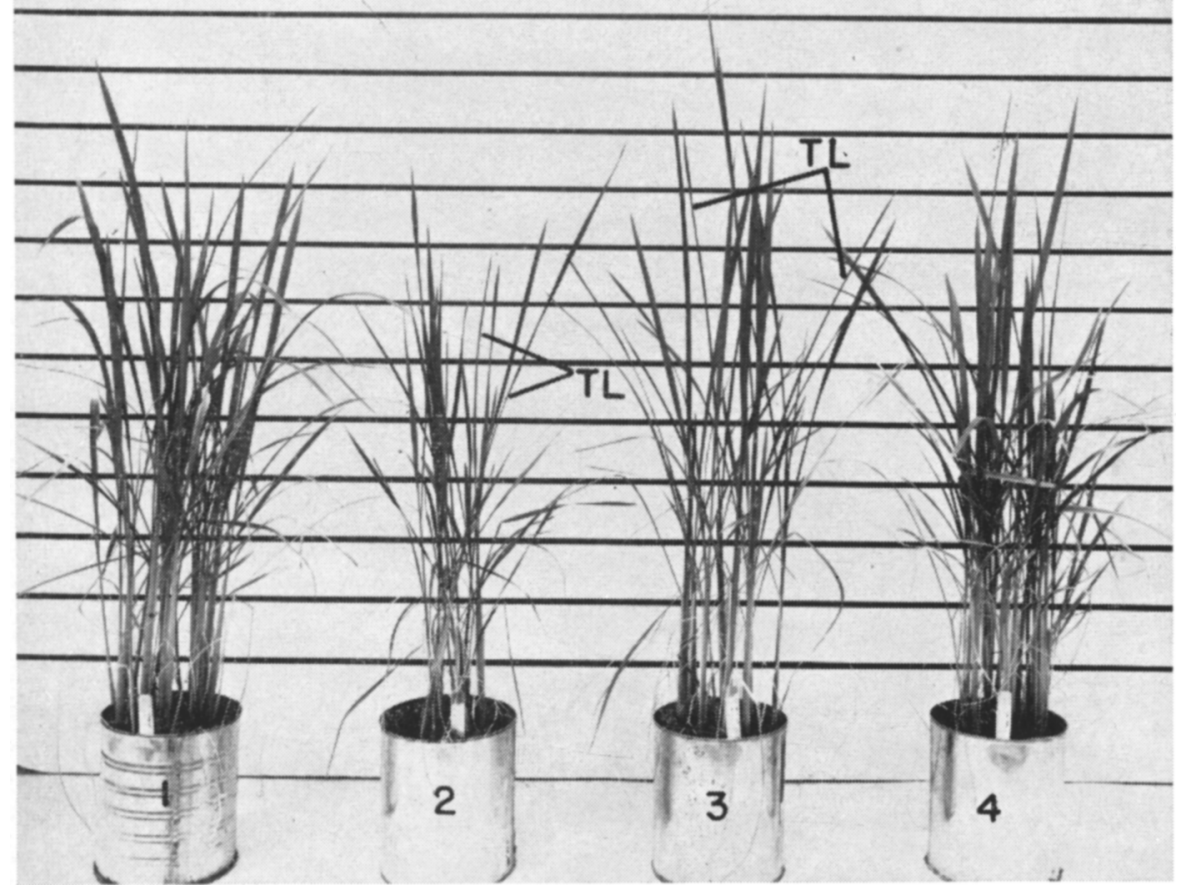

Fig. 2. Effect of method of planting on response of rice to amine MCP. Treated plants are representative of the first foliar application (15 days after planting). The dosage was 1.5 pounds acid equivalent per acre. 1 and $4=$ controls; $2=$ rice sown, treated; $3=$ rice drilled, treated. Note tubular leaves (TL) in cultures 2 and 3. 


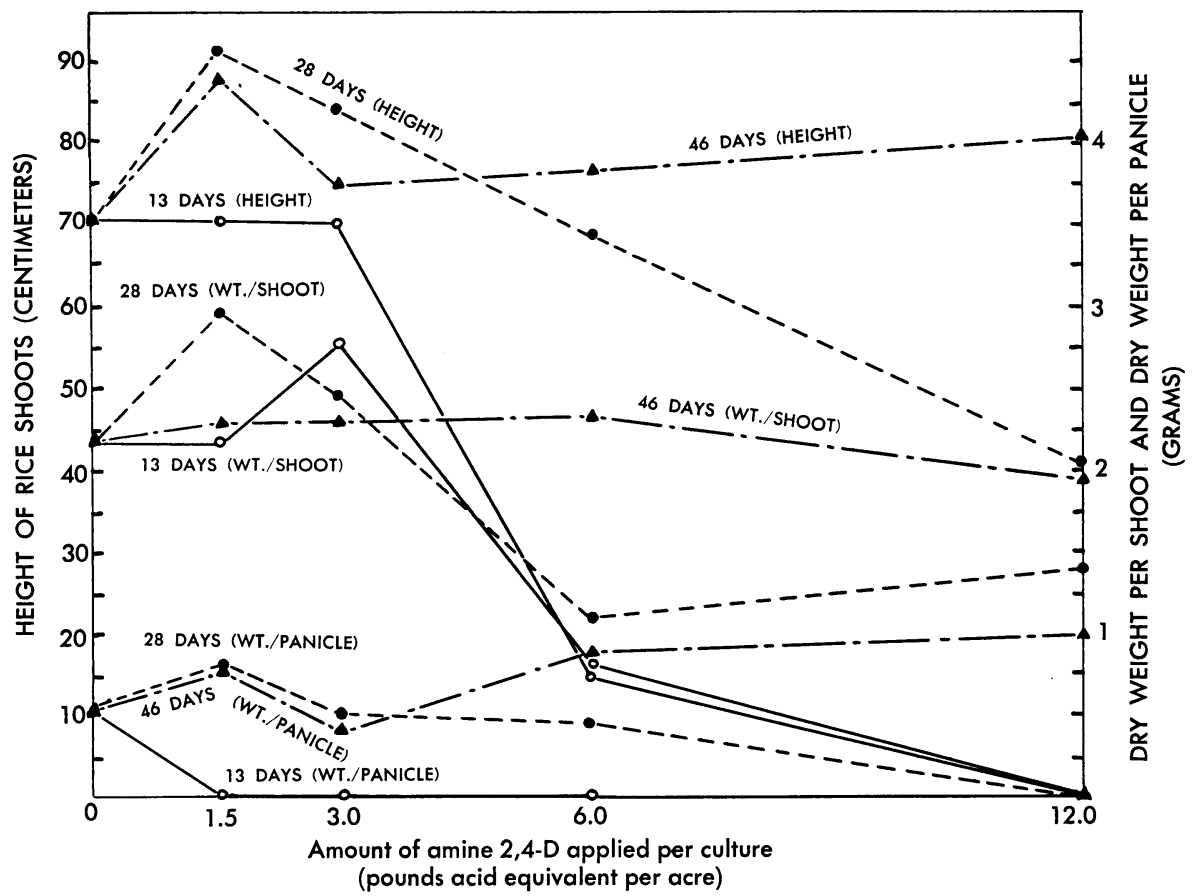

Fig. 3. Effect of time of application, in relation to stage of development, on several growth responses of rice plants to four dosages of amine 2,4-D applied to water in cultures in which rice was sown. 

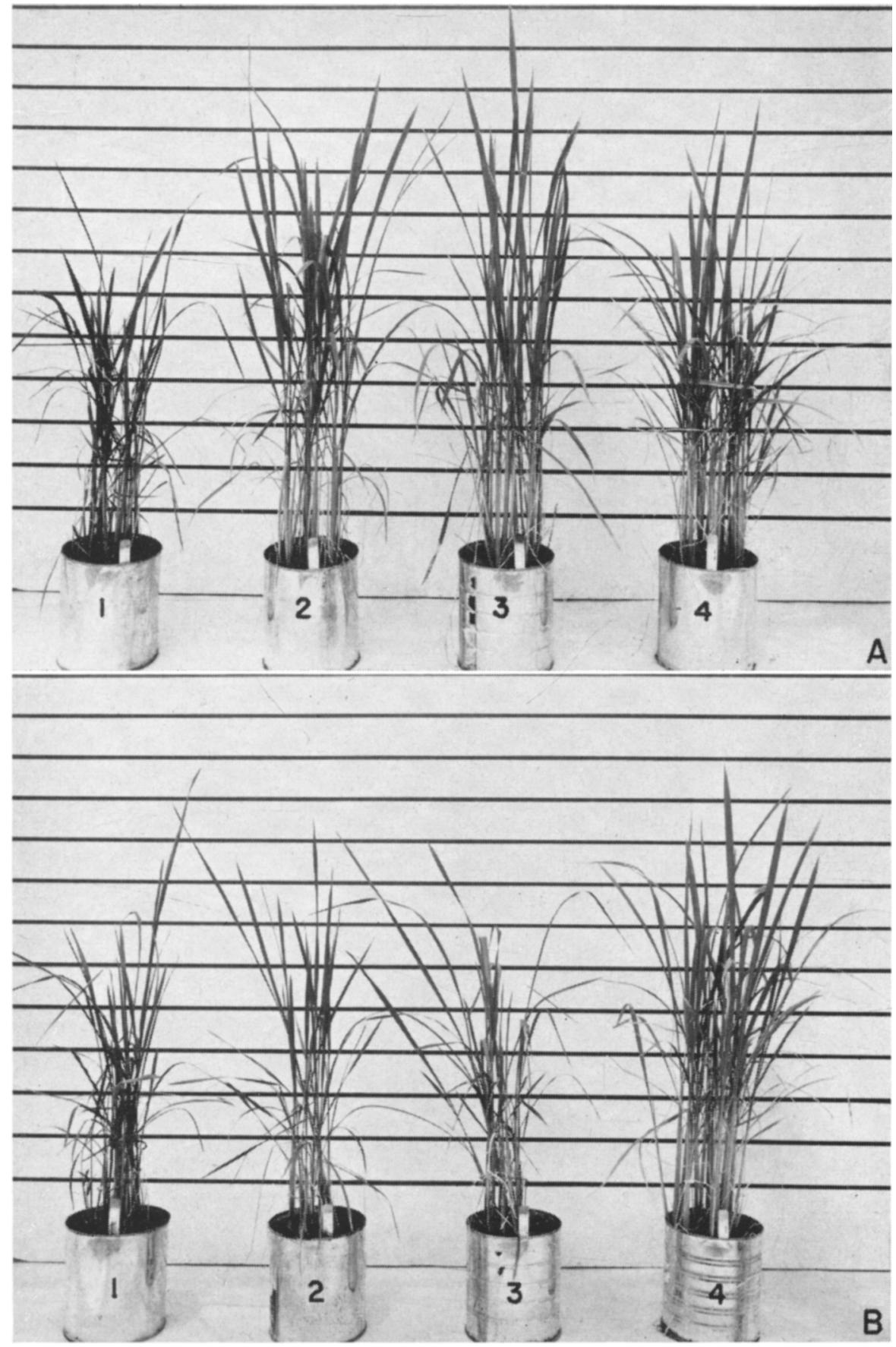

Fig. 4. Cultures treated with amine salts of 2,4-D (1), MCP (2), and 2,4,5-T (3) at a dosage of 1.5 pounds acid equivalent per acre. Culture 4 is control. Seed was sown. A. First foliar application series (15 days after planting) ; B. first water application series (13 days after planting). 


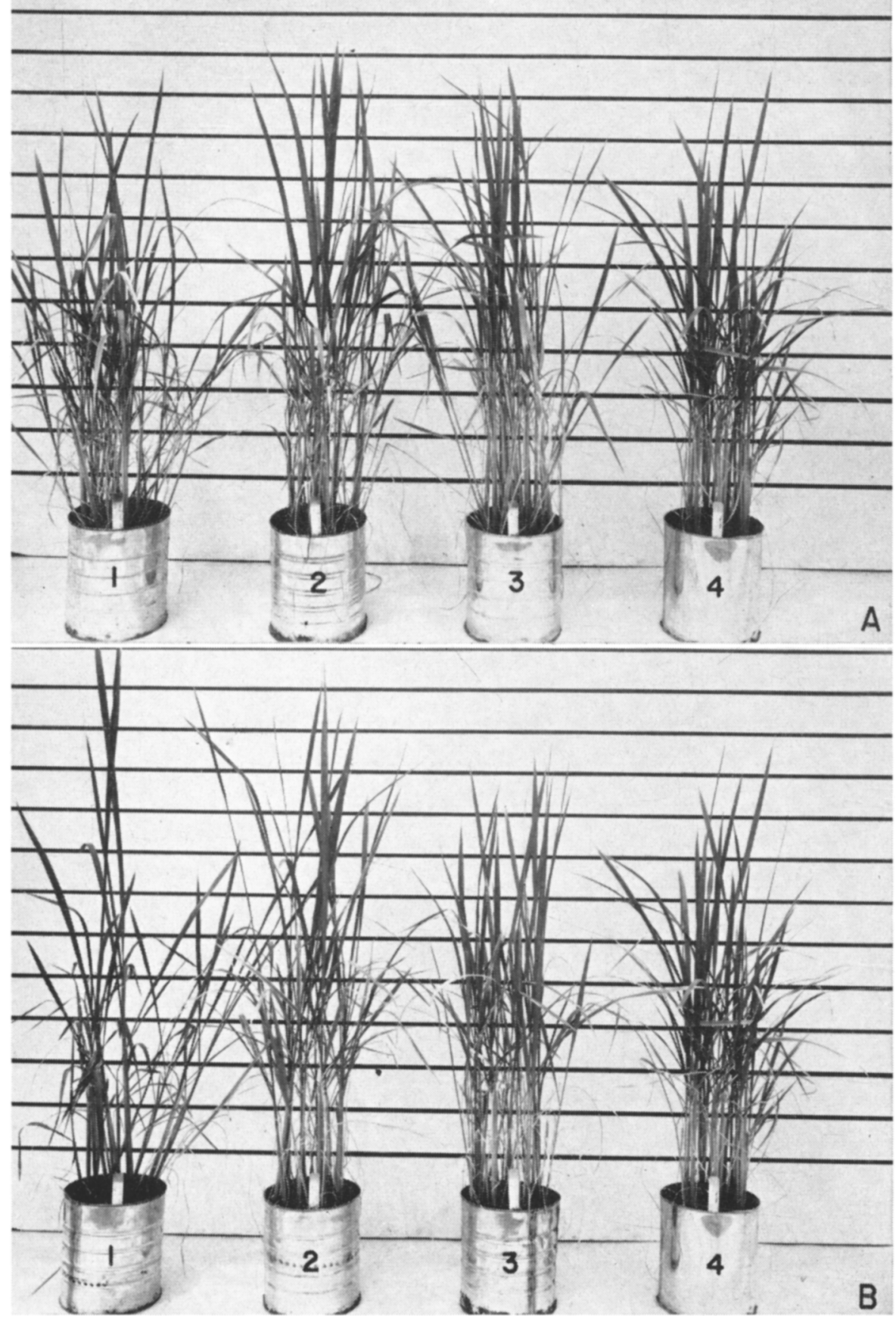

Fig. 5. Cultures treated with amine salts of 2,4-D (1), MCP (2), and 2,4,5-T (3) at a dosage of 1.5 pounds acid equivalent per acre. Culture 4 is control. Seed was sown. A. Third foliar application series (46 days after planting); B. third water application series (46 days after planting). 


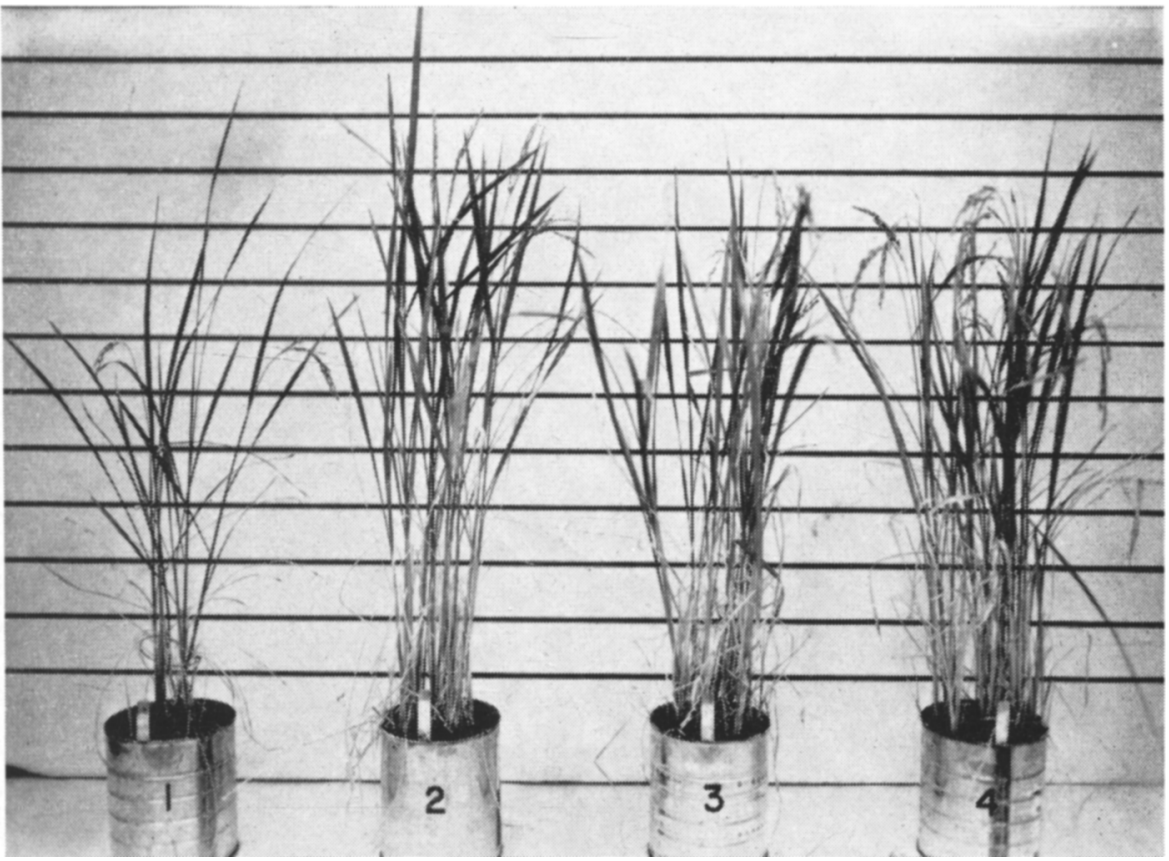

Fig. 6. Responses of rice to amine MCP applied to water at 3 pounds acid equivalent per acre on three different dates: $(1)=13$ days, $(2)=28$ days, $(3)=46$ days after planting. Culture 4 is control. Photographs were taken 95 days after planting. Seed was sown. Note diminution in heading and number of plants in culture 1 . 


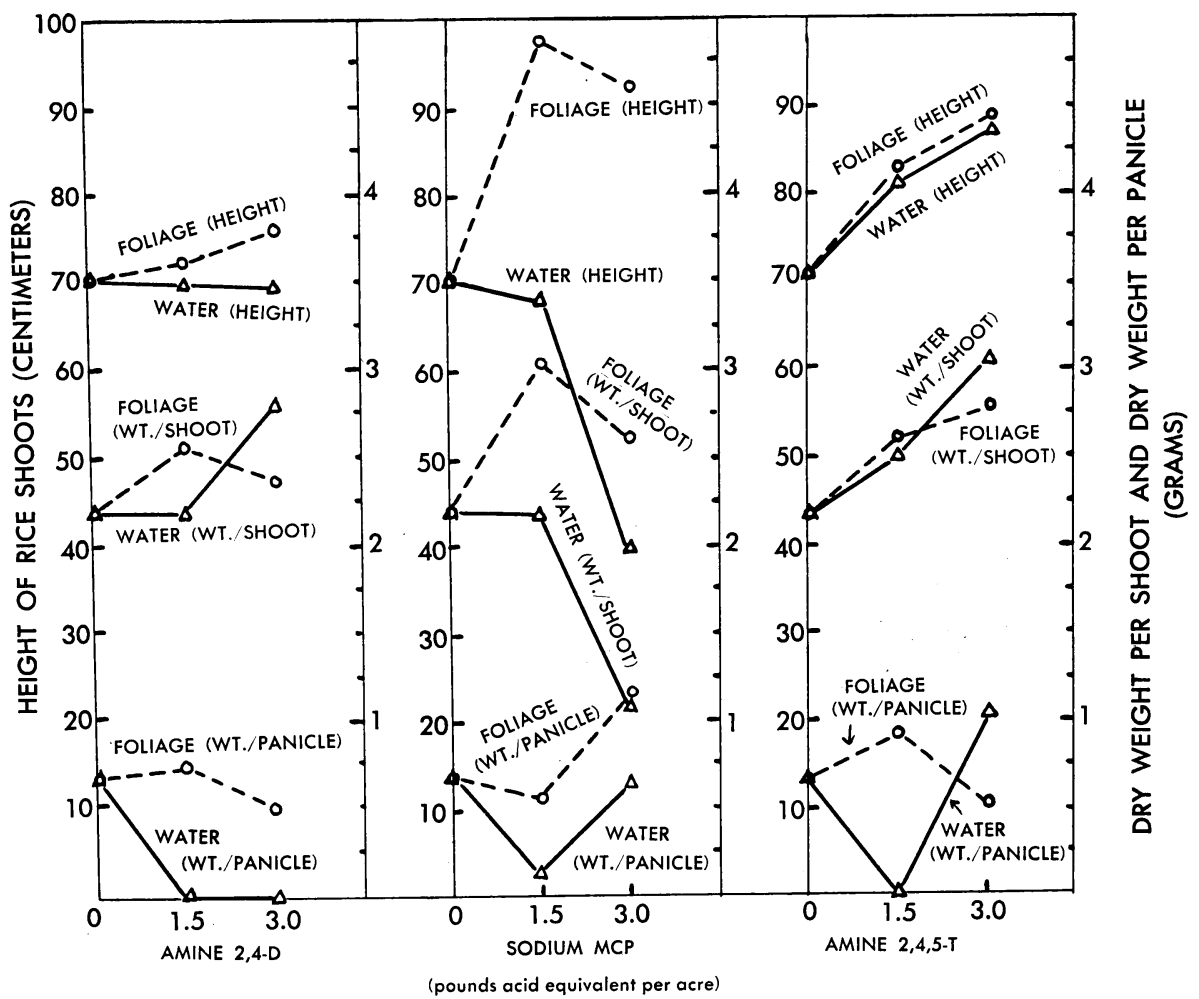

Fig. 7. Effect of method of application on several growth responses of rice plants to two concentrations of amine 2,4-D, sodium MCP, and amine 2,4,5-T applied (13 days after planting) to cultures in which rice was sown.

Fig. 8 (opposite page). Responses of rice to water applications (13 days after planting) of several growth regulators at three dosages: $(1)=6 ;(2)=3 ;(3)=1.5$ pounds acid equivalent per acre; $(4)=$ control. A. Amine MCP; B. amine 2,4-D; C. amine 2,4,5-T. Seed was sown. Observe absence of panicles in all of the 2,4-D treatments, and reduced heading in the MCP and 2,4,5-T treatments. 

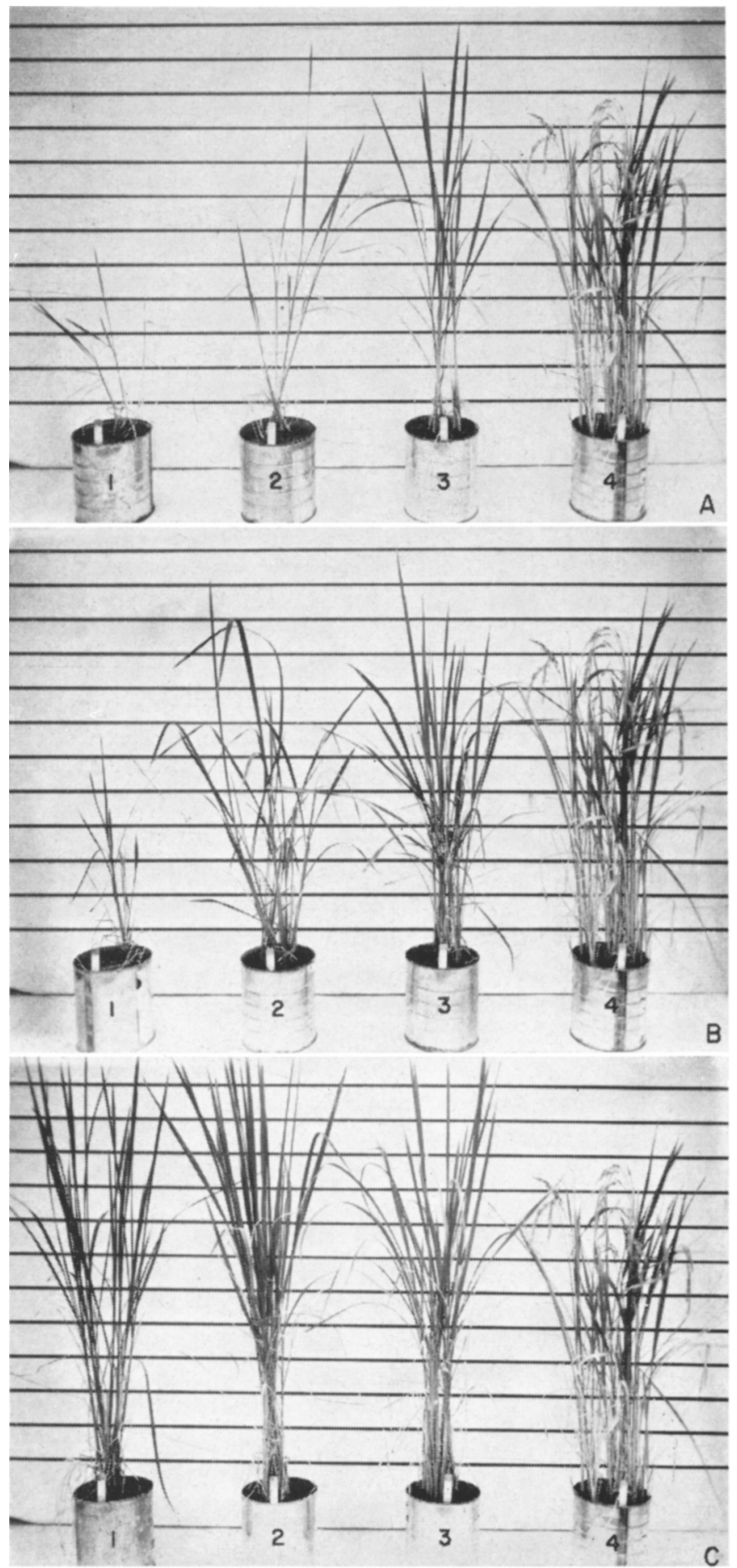


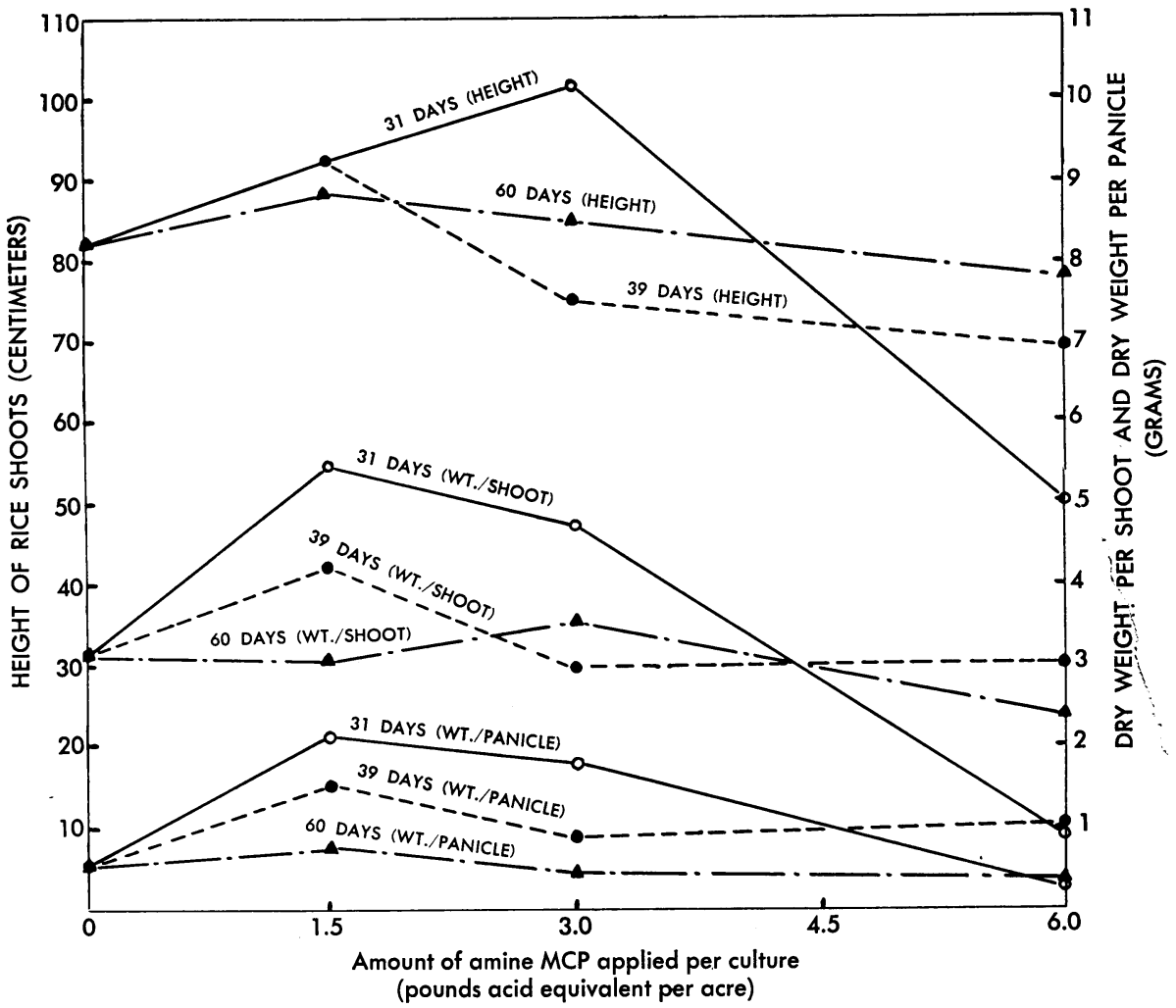

Fig. 9. Effect of time of application in relation to stage of development on several growth responses of rice plants to three dosages of amine MCP applied as pellets $(15 / 30$ screen mesh) to water in the cultures. 


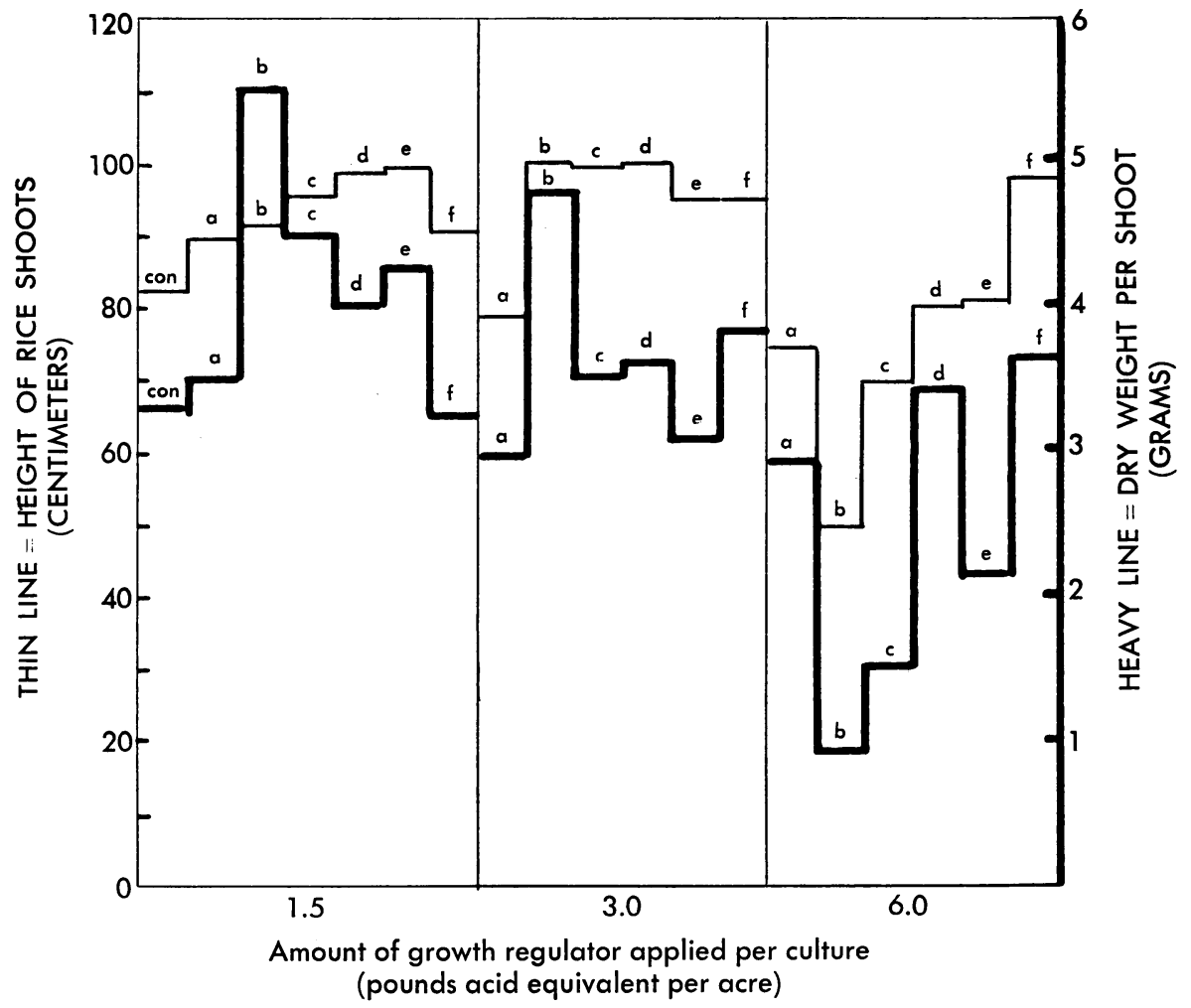

Fig. 10. Growth responses (height and weight per shoot) of rice to water applications (31 days after planting) of pelleted formulation (15/30 screen mesh) of several growth regulators (a: amine 2,4-D; b: amine MCP; $\mathrm{c}$ : sodium MCP; $d$ : potassium MCP; e: butyl ester MCP; $f$ : propylene glycol butyl ether ester 2,4,5-T; con: control) at three dosages. 


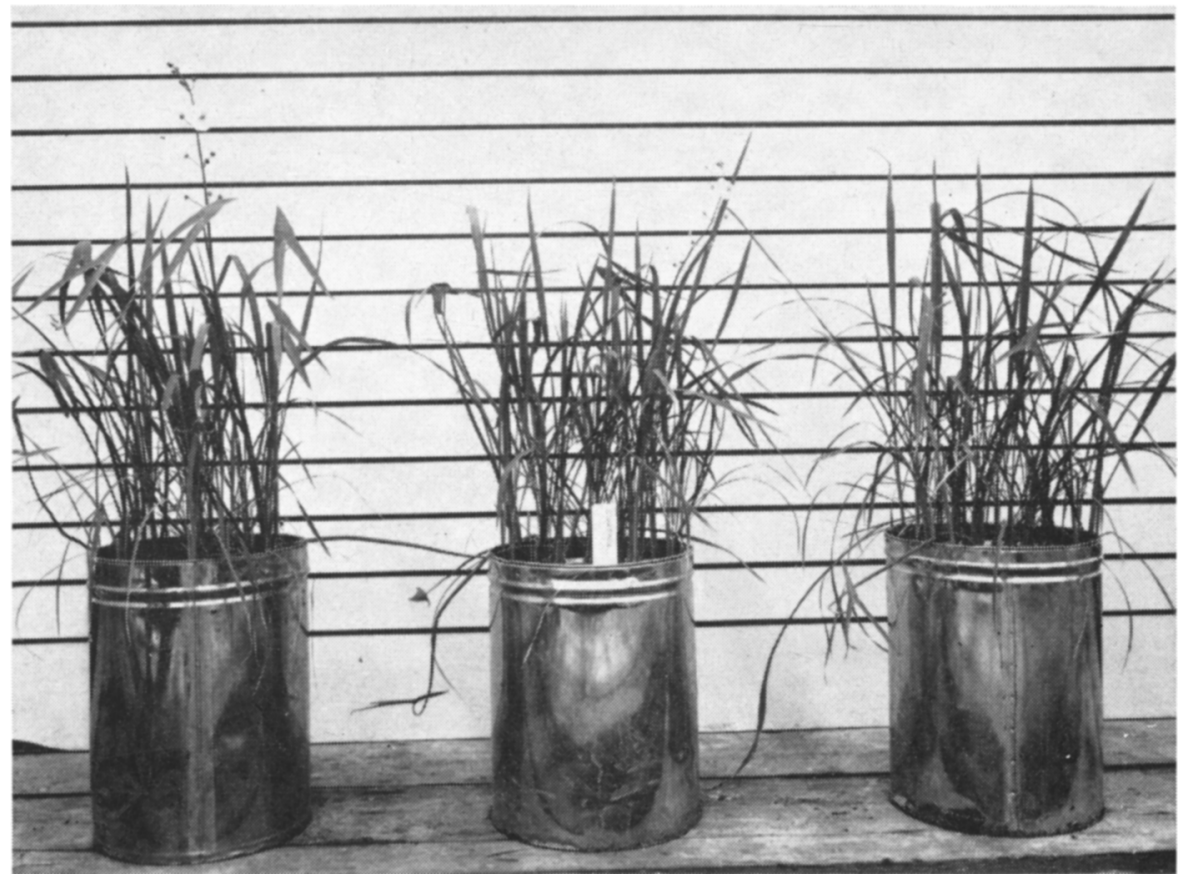

Fig. 11. Three untreated cultures of arrowhead (Sagittaria latifolia) and rice growing in 5-gallon containers.

Fig. 12 (opposite page). Responses of rice and arrowhead to water applications (31 days after planting) of pelleted formulations of several growth regulators at 1.5 pounds acid equivalent per acre. A. (1) = sodium $(2)=$ potassium MCP; $(3)=\operatorname{amine}$ MCP. B. $(1)=$ butyl ester MCP; (2) = propylene glycol butyl ether ester 2,4,5-T; $(3)=$ amine 2,4-D. Photographs were taken 17 days after treatment. $R P=$ rice panicle; $D A L=$ dead arrowhead leaf; $\mathrm{WP}=$ watergrass panicle; $\mathrm{IAL}=$ injured arrowhead leaves. 

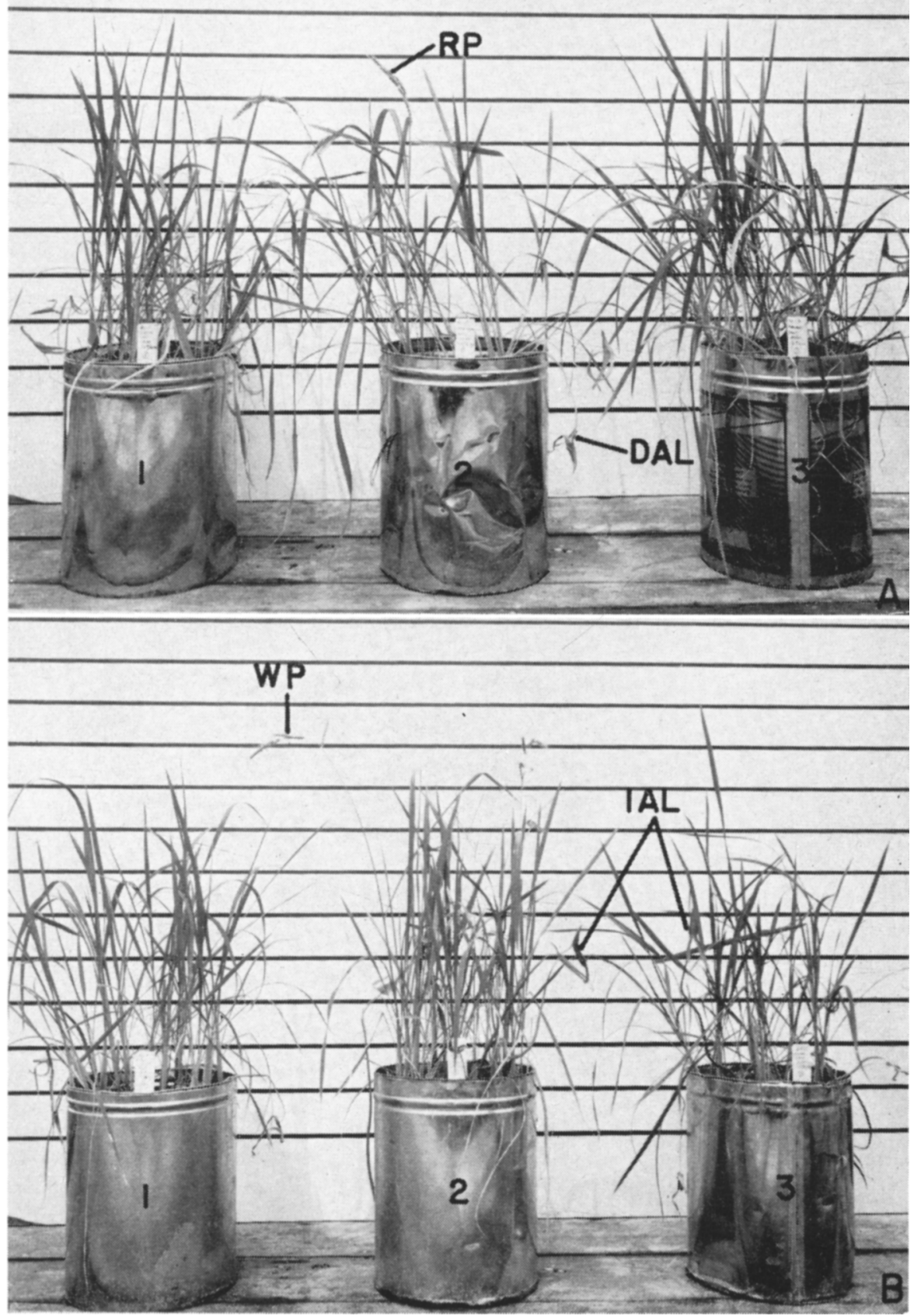


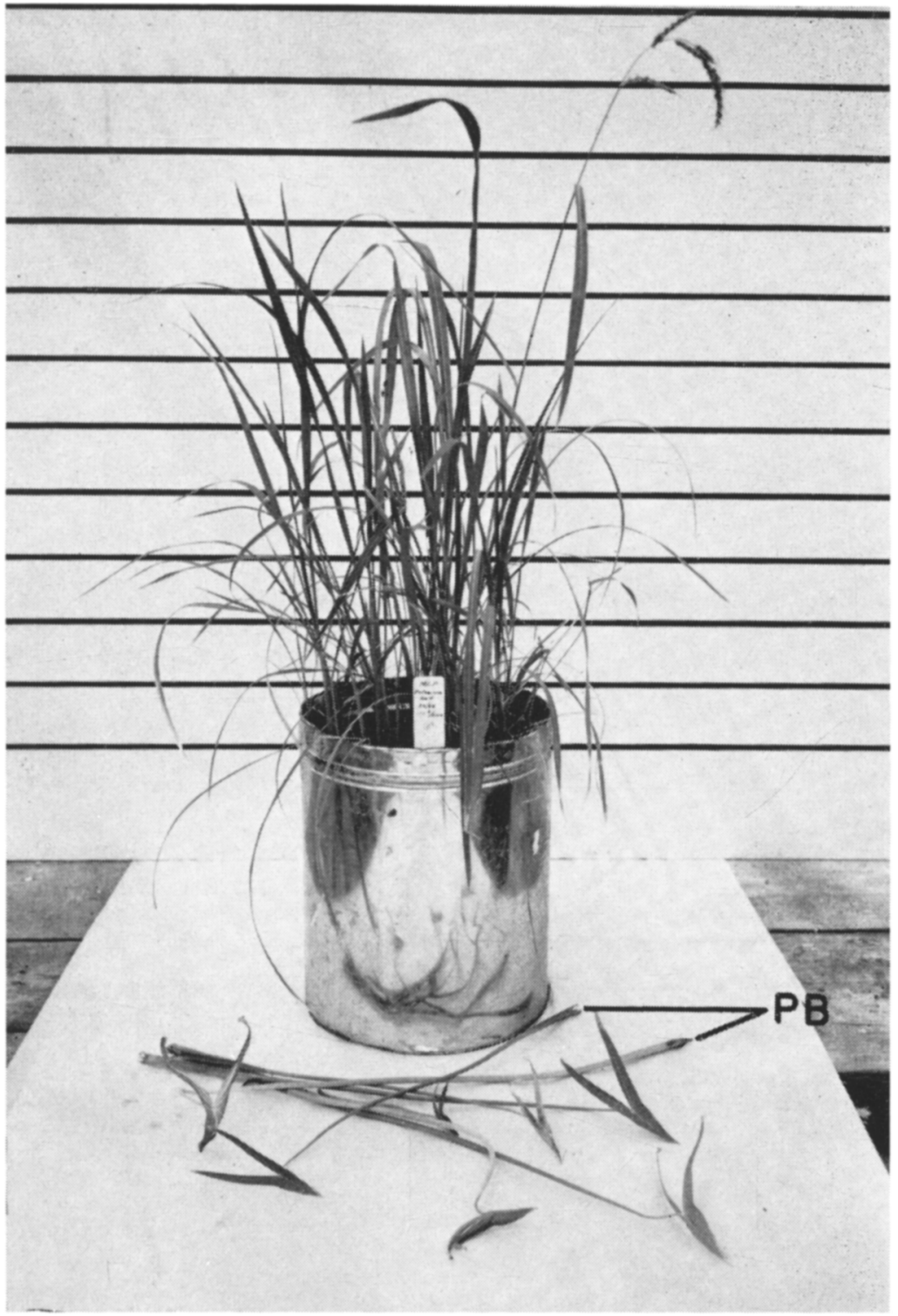

Fig. 13. Response of arrowhead, growing in a culture of rice, to pelleted potassium MCP (30/60 screen mesh) applied to water 39 days after planting, at a dosage of 1.5 pounds acid equivalent per acre. The petiole bases (PB) of the detached arrowhead leaves had already disintegrated at the time this photograph was taken (9 days after treatment). 


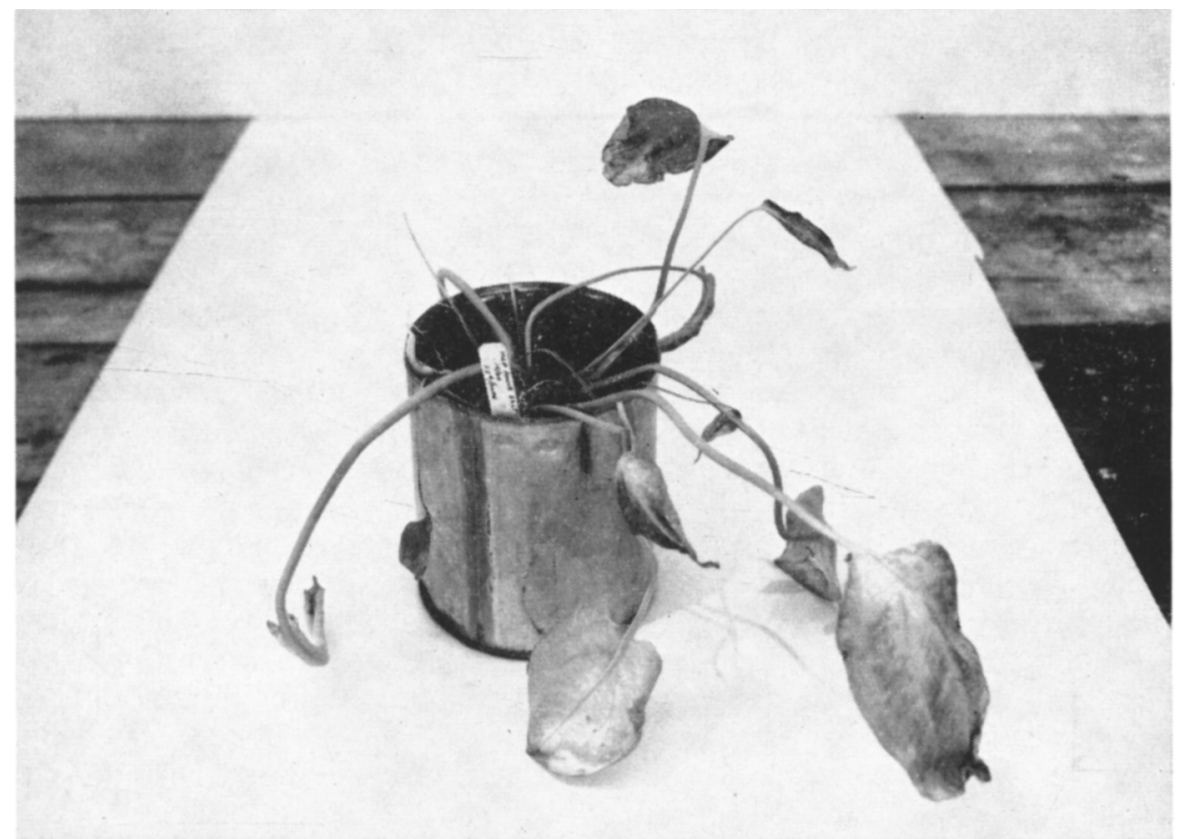

Fig. 14. Response of water plantain (Alisma Plantago) to pelleted amine MCP $(15 / 30$ screen mesh) applied to water during late vegetative stage at a dosage of 1.5 pounds acid equivalent per acre. Photograph illustrates slow death symptoms seven days after treatment. 


\section{Responses of Two Aquatic Weed Species Sown Without Rice}

In order to obtain a more complete picture of the responses of water plantain and arrowhead to treatments with pelleted formulations, cultures containing older vegetative plants were treated with $15 / 30$ screen mesh pellets of amine MCP at several dosages. No rice was included in the cultures, each of which contained one plant of each species. The experiments and results are described below.

Experiment with Water Plantain. In this test, each culture (1-gallon (can) was treated when the plants were about 12 inches high. (Plants in the rice-weed cultures were 0 to 6 inches high when treated.) Amine MCP was used at rates of $1.5,3,6$, and 12 pounds acid equivalent per acre. Within one day following treatment, typical curvature of stems and leaves was evident. After six days, yellowing of leaves was striking in cultures which received 3-, 6-, and 12-pound dosages; plants treated with the 1.5pound dosage had fewer yellow leaves, suggesting slower reaction or less phytotoxicity at this stage (fig. 14). At the end of seven days, the cultures receiving the 12-pound dosage exhibited the most intense aberrations; leaf bases had disintegrated, and leaves and stems were highly chlorotic. These effects were progressively less severe in the $6-, 3-$, and 1.5 -pound treatments, respectively, at this period of observation. After nine days, stems and leaves in the 3-, 6-, and 12-pound treatments exhibited complete necrosis. Leaves of plants in the 1.5-pound cultures were dead, but stems remained alive. By 15 days, plants in all cultures were dead, indicating complete phytotoxicity within the dosage range of 1.5 to 12 pounds acid equivalent per acre with amine MCP.

Experiment with Arrowhead. This test was made to determine whether dosages of less than 1.5 pounds acid equivalent per acre would be phytotoxic to large vegetative (preflowering stage) plants. Pellets of amine MCP were applied to 50-day-old cultures at a dosage of 0.75 pound acid equivalent per acre. After four days, many leaf blades were chlorotic, and stems were twisted in the preflowering stage. By the end of six days, older stems and leaves were chlorotic, but little tissue disintegration had occurred at leaf petiole bases (fig. 13). Curvature of stems was most apparent at the tips of young, inflorescence branches. Observations on the twenty-fourth day revealed (1) that outer, older leaves were dead; (2) that younger leaves formed after treatment were twisted and depauperate but still green and alive; (3) that there was little or no basal disintegration of leaves, as is usual when complete control is obtained; (4) that the inflorescence axis and branches were somewhat twisted but still alive; and (5) that flowering had occurred, but no seed was produced. It was concluded that the treatment was partially effective, in that seeds were not produced and potential competition between the injured plants and rice was diminished. Treatments made at much earlier stages of development would probably have controlled the arrowhead.

\section{DISCUSSION}

Airplane spraying of rice fields with 2,4-D, for control of weeds, is common practice in California and a number of southern states. Experiments described in this report were aimed at eliminating some of the problems 
inherent in this practice, two of which are injury to rice and damage to sensitive crops by spray drift. This discussion evaluates results of the experiments in relation to the objectives and to previous findings, and suggests field practices.

\section{Application of Aqueous Solutions of Growth Regulators to Rice}

In this series of tests several critical factors that influence the response of rice to spray treatments were considered: (1) Are differences in intensity of the responses of rice plants to growth regulator treatments related to planting methods? (2) Are there clearly defined differences in growth responses of rice when growth regulators are applied as spray to leaves, as compared with application in solution through the water which covers the roots? (3) Is the relation of time of treatment to stage of development critical in these two methods of treatment? (4) What are the comparative growth responses of rice to applications of closely related plant growth regulators at various dosage levels? (5) How do the significant results of such tests relate to field practices of weed control in rice?

Differences in growth responses of drilled and sown rice were conclusively demonstrated in these tests (see pages 440 and 447). Sown rice with its roots exposed on the soil surface consistently responded more intensely than did drilled rice. In the former, morphologically and physiologically sensitive tissues of the shoot base, shoot-root transition, and upper root system are openly exposed to the growth regulator present in the water which floods them. Kaufman $(1954,1955)$ has shown such tissues to be responsive to 2,4-D. Furthermore, large numbers of adventitious roots are initiated and develop in treated plants (see aberration indices 1 and 2 for rice in table 3 ). These constitute the entire root system of the rice plant after seminal roots reach senescense in seedlings.

Where rice is drilled, these shoot regions and adventitious root systems are situated in the soil below the water contaminated by growth regulator. Since the soil in many rice growing regions is heavy, the growth regulator may be relatively unavailable as a result of adsorption to the clay. This needs further study because physical adsorption and biological breakdown may be factors determining the differences in response of sown and drilled rice to growth regulator treatments.

Evidence that water treatments with growth regulators cause more damage to rice than does application to leaves (Kaufman, 1953) is confirmed in these tests. Such effects were most apparent in cultures treated at the earliest stage with the highest dosages of 2,4-D and MCP. These observations may explain the greater phytotoxicity noted in the water treatments.

Considering the tissues of the rice plant most markedly affected by 2,4-D, that is, leaf primordia, young leaves and telescoped nodes and internodes, primordial axillary buds, and recently initiated adventitious roots, it is apparent that these labile tissues are most definitely exposed to the growth regulator in the water surrounding the plants. More mature tissues, such as older leaves, stems, and axillary shoots, are less reactive and, in the case of water treatment, less exposed. They are little affected by such treat- 
ment. If we assume that more growth regulator actually enters the plant (and over a longer period of time in the case of the treatment through water), hence that the toxicant is present in the sensitive tissues in larger amounts, and that translocation is less critical because of the immediate contact, we have a basis for explaining the greater phytotoxicity shown by the water treatments. With foliar application, it is necessary to allow for some growth regulator entering the water around the rice plants. In practice this was found to be negligible in comparison with the amount actually intercepted by the leaves at the proper stage for spraying. The greater damage to rice from 2,4-D applied early in the season probably reflects the greater proportion of the chemical that reaches the water. In pretillering stages, a relatively large water surface is exposed as compared with later stages when the dense foliage of the rice shades the water and intercepts the spray.

Responses of rice to treatments made at various stages of development corroborate previous tests; injury is less intense with successive treatments. This is most apparent in the water treatments. Considering the development of the rice plant it seems evident that: (1) The ratio of sensitive meristematic tissues to mature, nonreactive tissues diminishes in successively older plants. (2) A buffer region of nonreactive portions of the plant increases in extent with time. (3) The amount of potential absorptive area and the length and number of translocation pathways increase markedly with time, resulting in an effective dilution of the active chemical agent. (4) Inactivation or metabolism of growth regulator in nonreactive tissues may possibly occur to an increasing extent with maturity. Some such phenomenon must explain the violent reaction of seedlings as compared with the paucity of aberrations in mature plants.

Previous comparative studies on the toxicity of several growth regulators on rice have been confirmed by the present studies. The order of intensity of deleterious effects resulting from treatment with the three materials is, with few exceptions, 2,4-D, MCP, 2,4,5-T. This trend was most clearly expressed in water treatments at the highest dosage levels on rice at the youngest stage of development. It is interesting to note that, in the gross bioassay tests with rice, treatments with sodium and triethanolamine salts of MCP gave responses of similar intensity. It would be of further interest to find whether this relation would be substantiated by more refined bioassay methods, such as the Avena curvature test, the Avena coleoptile section test, and split pea stem curvature and root elongation tests (Veldstra, 1953).

In earlier experiments, using a dosage range of 0.94 to 1.56 pounds acid equivalent per acre, no significant differences in growth responses of rice could be detected. By expanding the dosage range to 1.5 to 12 pounds acid equivalent per acre in the recent tests, there was a perceptible magnification in the intensity of growth aberrations at successively higher dosages. This statement should be qualified, however. A growth stimulation was noted with the lower doses (1.5 and 3 pounds) in the foliar applications, and the dosage-growth response progressively diminished in successive treatments. It seems probable that the growth stimulation consisted of an increase in internodal elongation in vegetative shoots (hence an increase in height) 
and an acceleration of cell division and enlargement in leaves (Kaufman, $1954,1955)$. Treatments with the same dosages at earlier stages of development, especially during periods of high temperature, would have been more phytotoxic.

The following generalizations, derived from previous and current investigations on rice, may relate to field practices: (1) Other things being equal, it is highly probable that field-drilled rice will not be so severely injured as will airplane-sown rice when treated with growth regulator herbicides. This is especially true when application is made on young plants. Obviously, this factor cannot be easily remedied where rice is airplane sown. Nevertheless, potential injury may be reduced by waiting until the rice is in the tillering stages, by keeping the water high, and by avoiding application during excessively hot weather (water temperature $100^{\circ} \mathrm{F}$ or above). (2) Greater injury may be expected when the growth of rice is sparse or scattered. Uniform, adequate seeding is therefore essential if injury is to be minimized. (3) MCP should be used in preference to 2,4-D if, for any reason, injury is anticipated. This material costs more than 2,4-D, but the over-all costs on an acre basis are such that loss from 2,4-D injury may greatly exceed the differential in herbicide cost. (4) The dosage range for weed control in rice varies from 10 to 25 ounces acid equivalent per acre. The higher range is used where sedges and cattails are prevalent. While many fields have received treatment within this range without injury, higher dosages may be inadvisable since greenhouse and field tests show deleterious effects from treatments in the 4- to 12-pound range. Other materials, such as 2,4-dichlorophenoxypropionic acid and 2-methyl, 4-chlorophenoxypropionic acid, are being tested in a search for a material of higher selectivity than 2,4-D or MCP.

\section{Application of Pelleted Formulations of Growth Regulators to Rice and to Weeds}

If pelleted formulations of growth regulators could be used on rice and aquatic weeds, problems of drift and volatilization would be solved. However, their use involves several critical considerations: (1) Are pelleted materials, acting through the water, selective enough to handle the weeds without injury to the crop? (2) Will the time of application-stage of development relations worked out for spray applications hold? (3) What range of dosage will be required? (4) Are other technical or practical problems involved in their use?

The current studies have shown beyond doubt that some important weeds of rice can be controlled by pelleted formulations of several growth regulators without serious injury to rice. Sedges and cattails were not included because they are difficult to establish under pot culture conditions. When time of treatment with pelleted growth regulators (except 2,4,5-T and butyl ester of MCP) was made to coincide with a certain stage of rice and aquatic weed development, the materials stimulated growth at the 1.5- and 3-pound dosages. Moreover, growth inhibition of rice gradually diminished, at the 6-pound dosage, from the first to the last dates of application. Control of aquatic weeds was effected with the 3 - and 6-pound dosages of 2,4-D and 
MCP compounds, the degree of control being greatest with the early treatment. These responses tend to corroborate time of treatment-stage of development results obtained earlier with foliar applications of aqueous solutions.

The marked stimulatory growth responses of rice noted with the lower dosages, even at the earliest application date, and the consequent shift in intensity of injury effects, from lower to higher dosages, are unique to the pellet treatments. This may be explained by the fact that pellets dissolve slowly, resulting in a lower concentration of toxicant per unit volume of water than is present following spray treatment or application directly through the water. Furthermore, the pellets immersed in mud release the growth regulator directly to the clay colloids of the soil where a certain portion is undoubtedly adsorbed. With less growth regulator present at any one time in the external water phase, less would be absorbed and translocated to sensitive tissues. Hence the regulator in these regions would be present at stimulatory rather than inhibitory levels in the case of the lower dosages. At the 6-pound dosage, the concentration was apparently at the inhibitory level, and growth was reduced. Apparently the susceptibility of tissues of the aquatic weeds is greater than that of rice as evidenced by complete phytotoxicity at all stages of treatment of the weeds at the 3 - and 6-pound dosages of 2,4-D and MCP. Lowered intensity of growth inhibition and of phytotoxicity to rice and weeds at successively later treatment dates is in accord with suggestions made on pages 414 and 416 .

Comparing results of treating rice and aquatic weeds with pelleted formulations of a number of growth regulators brings out several trends, notably: (1) absence of deleterious effects on rice, and mild formative effects on weeds for 2,4,5-T treatments at most dosage levels; (2) growth stimulation of rice with low dosages of MCP and 2,4-D ; (3) growth inhibition of rice at the high dosage levels, the effect diminishing at successive dates of treatment; (4) effective control of aquatic weeds with 2,4-D and MCP, the potassium salt of MCP being the most toxic, followed by other MCP salts and 2,4-D. The toxicity of $2,4,5-\mathrm{T}$ is evidently insufficient to provide practical weed control in rice.

From these greenhouse tests it seems that pelleted formulations of growth regulators may be less severe on rice than are spray treatments at comparable dosages, yet toxic enough to control aquatic weeds. This might allow for use of somewhat higher dosages, particularly on rice at the tillering stage or later. There is also the suggestion that the potassium salt of MCP might be more effective than some other salts or esters when used in the pelleted form. Field testing will be needed to confirm these observations.

Within the limits of the dosage range employed, namely, 1.5 to 6 pounds, remarkable variations in response of both rice and weeds were observed: (1) control of the weeds over the entire range, except with $2,4,5-\mathrm{T}$; the most complete toxicity was obtained at the earliest stages and at the highest dosages; (2) little or no injury to rice with the later applications, irrespective of dosage; (3) stimulatory responses at the 1.5- and 3-pound dosages, and concomitant inhibitory responses at the 6-pound dosage in the earlier applications to rice. These observations shed considerable light on the question of range of dosage. Our tests suggest that selectivity of the pelleted 
formulations varies indirectly with dosage and directly with the age of the rice. In other words, the selectivity increases with applications to successively older rice plants as inferred from the dosage-response data (fig. 9). Moderate selectivity is present at the 1.5- (and possibly 3-) pound dosage level in the earliest applications. In the latest applications, the selectivity increases as a consequence of little or no phytotoxicity to rice at all dosage levels.

From the results reported herein, it seems possible that pelleted forms of growth regulators may find use in weed control in rice. However, before a firm recommendation can be made, detailed field tests must be conducted. Some of the factors that must be studied in the field are: (1) time of treatment (growth stage); (2) type of growth regulator; (3) dosage; (4) air and water temperature in relation to treatment date; (5) density of rice stand; (6) height of water level in rice checks; and (7) mechanies of pellet application, especially in relation to possible air pollution by dust from the pellets.

\section{SUMMARY}

Continuing the investigations on the responses of the rice plant to growth regulator herbicides, this paper reports on comparative treatments with aqueous and pelleted formulations of several compounds. Important variables were: method of planting of rice seed; stage of development of rice plants in relation to time of application ; method of application ; and formulation, type, and dosage of growth regulator. The following conclusions are drawn from these researches:

(1) In treatments with aqueous solutions, the most striking deleterious effects in rice were obtained when: (a) rice seed was sown; (b) rice was treated at younger stages of development; (c) applications were made to water surrounding rice plants; (d) the growth regulator was applied at the highest dosages; and (e) the growth regulator applied was 2,4-D.

(2) In treatments with pelleted formulations, the most intense aberrations in rice and aquatic weeds were observed when: (a) plants were treated at the youngest stages of development; (b) the growth regulator was applied at the highest dosage; and (c) the growth regulator applied was 2,4-D.

(3) In comparing treatments with aqueous solutions and pelleted formulations, it was notably clear that pellets are more selective at equivalent dosages.

(4) Pelleted formulations of growth regulators effectively control aquatic weeds in rice cultures and can concurrently bring about growth stimulation in rice at low dosage levels.

Some of the physiological, morphological, and agricultural implications of these findings are discussed. 


\section{LITERATURE CITED}

CRAFTs, A. S.

1935. The toxicity of sodium arsenite and sodium chlorate in four California soils. Hilgardia 9(9):461-98.

KAUPMAN, P. B.

1953. Gross morphological responses of the rice plant to 2,4-D. Weeds $2: 223-53$.

1954. Development of the shoot of Oryza sativa L. Dissertation for the degree Doctor of Philosophy, University of California.

1955. Histological responses of the rice plant (Oryza sativa) to 2,4-D. Amer. Jour. Bot. $42: 649-59$.

VELDSTRA, H.

1953. The relation of chemical structure to biological activity in growth substances. Ann. Rev. Plant Physiol. 4:151-98. 
Tables 3-9 inclusive appear on pages 440-453 
TABLE 3

RESPONSE OF DRILLED AND SOWN RICE TO AMINE 2,4-D APPLIED

Nоте: The following is a key to the aberration indices for rice in column 5 :

$1=$ excessive numbers of massive adventitious roots at base of shoot.

$2=$ base of shoot swollen due to presence of proliferating adventitious root and stem tissue.

$3=$ twisting or curvature of elongating internodes.

$4=$ accelerated elongation of internodes.

$5=$ proliferation of axillary buds (young tiller shoots) at base of parent shoot.

$\mathbf{6}=$ aberrant emergence of young inner leaves from sheaths of older leaves, i.e., buckling out.

Numbers in boldface in the column indicate that the symptom was

\begin{tabular}{|c|c|c|c|c|c|}
\hline \multicolumn{6}{|c|}{ TREATMENT } \\
\hline Method of planting & $\begin{array}{l}\text { Age of plants } \\
\text { at treatment } \\
\text { time }\end{array}$ & $\begin{array}{l}\text { Method of } \\
\text { application } \\
\text { of } 2,4-D\end{array}$ & $\begin{array}{l}\text { Pounds acid } \\
\text { equivalent per } \\
\text { acre applied }\end{array}$ & Aberration indices for rice & $\begin{array}{l}\text { Number of } \\
\text { plants per } \\
\text { culture* }\end{array}$ \\
\hline Sown & $\begin{array}{c}\text { days } \\
13 \\
13 \\
13 \\
13 \\
15 \\
15\end{array}$ & $\begin{array}{l}\text { water } \\
\text { water } \\
\text { water } \\
\text { water } \\
\text { foliage } \\
\text { foliage }\end{array}$ & $\begin{array}{r}1.5 \\
3.0 \\
6.0 \\
12.0 \\
1.5 \\
3.0\end{array}$ & $\begin{array}{l}1,2,4,7,11 \\
1,2,4,6,7,8,10,11 \\
1,2,4,6,8,10,11,12 \\
2,3,6,8,10,11,12 \\
1,2,4,7,11 \\
1,2,4,8,10,11\end{array}$ & $\begin{array}{l}9.5 \\
6.0 \\
1.5 \\
0.0 \\
9.0 \\
9.5\end{array}$ \\
\hline Drilled & $\begin{array}{l}13 \\
13 \\
13 \\
13 \\
15 \\
15\end{array}$ & $\begin{array}{l}\text { water } \\
\text { water } \\
\text { water } \\
\text { water } \\
\text { foliage } \\
\text { foliage }\end{array}$ & $\begin{array}{r}1.5 \\
3.0 \\
6.0 \\
12.0 \\
1.5 \\
3.0\end{array}$ & $\begin{array}{l}4,7 \\
1,4,7,11 \\
1,2,4,6,7,8,10,11 \\
1,2,4,6,10,11 \\
13 \\
1,4,7\end{array}$ & $\begin{array}{r}8.0 \\
11.0 \\
9.5 \\
4.5 \\
11.0 \\
8.0\end{array}$ \\
\hline Sown & $\begin{array}{l}28 \\
28 \\
28 \\
28 \\
28 \\
28\end{array}$ & $\begin{array}{l}\text { water } \\
\text { water } \\
\text { water } \\
\text { water } \\
\text { foliage } \\
\text { foliage }\end{array}$ & $\begin{array}{r}1.5 \\
3.0 \\
6.0 \\
12.0 \\
1.5 \\
3.0\end{array}$ & $\begin{array}{l}1,2,4 \\
1,2,4,11 \\
1,2,4,11 \\
1,2,4,5,6,10,11 \\
1,4 \\
1,2,4\end{array}$ & $\begin{array}{r}10.0 \\
11.5 \\
9.0 \\
7.0 \\
13.0 \\
12.5\end{array}$ \\
\hline Drilled & $\begin{array}{l}28 \\
28 \\
28 \\
28 \\
28 \\
28\end{array}$ & $\begin{array}{l}\text { water } \\
\text { water } \\
\text { water } \\
\text { water } \\
\text { foliage } \\
\text { foliage. }\end{array}$ & $\begin{array}{r}1.5 \\
3.0 \\
6.0 \\
12.0 \\
1.5 \\
3.0\end{array}$ & $\begin{array}{l}1,2,4 \\
1,2,4 \\
1,2,4 \\
1,2,4,6,10,11 \\
1 \\
1,2,4\end{array}$ & $\begin{array}{r}10.0 \\
10.5 \\
9.5 \\
5.5 \\
11.0 \\
11.0\end{array}$ \\
\hline Sown & $\begin{array}{l}46 \\
46 \\
46 \\
46 \\
46 \\
46\end{array}$ & $\begin{array}{l}\text { water } \\
\text { water } \\
\text { water } \\
\text { water } \\
\text { foliage } \\
\text { foliage }\end{array}$ & $\begin{array}{r}1.5 \\
3.0 \\
6.0 \\
12.0 \\
1.5 \\
3.0\end{array}$ & $\begin{array}{l}1,4,9 \\
1,2,4 \\
1,2,4 \\
1,2,4 \\
1,2,4 \\
1,2,4\end{array}$ & $\begin{array}{r}10.0 \\
9.5 \\
10.0 \\
12.5 \\
12.0 \\
14.0\end{array}$ \\
\hline Drilled & $\begin{array}{l}46 \\
46 \\
46 \\
46 \\
46 \\
46\end{array}$ & $\begin{array}{l}\text { water } \\
\text { water } \\
\text { water } \\
\text { water } \\
\text { foliage } \\
\text { foliage }\end{array}$ & $\begin{array}{r}1.5 \\
3.0 \\
6.0 \\
12.0 \\
1.5 \\
3.0\end{array}$ & $\begin{array}{l}1,4 \\
1,4 \\
1,4 \\
1,2,4 \\
13 \\
2\end{array}$ & $\begin{array}{r}9.0 \\
11.0 \\
13.0 \\
11.5 \\
10.0 \\
12.5\end{array}$ \\
\hline Sown.... & .. & $\ldots \ldots$ & control $\dagger$ & 13 & 12.3 \\
\hline
\end{tabular}

* Initial number of plants per culture varied from 10 to 15 .

$\dagger$ Based upon an average of 11 control replicates. 
$7=$ twisted and tubular leaves.

$8=$ precocious yellowing of leaves.

$9=$ presence of exceptionally tall leaves due to stimulated leaf elongation.

$10=$ reduced height of shoots due to premature leaf and internode maturation.

$11=$ shoots lodged due to weak and excessively elongated internodes.

$12=$ entire plant dead.

$13=$ vegetative plants expressing no aberrations.

more intense than the others listed for that particular treatment.

\begin{tabular}{|c|c|c|c|c|c|c|}
\hline \multicolumn{7}{|c|}{ RESULTS $\$ \S$} \\
\hline $\begin{array}{l}\text { Average height } \\
\text { of plants } \\
\text { per culture }\end{array}$ & $\begin{array}{c}\text { Dry weight } \\
\text { of shoots } \| \\
\text { per culture }\end{array}$ & $\begin{array}{c}\text { Dry weight } \\
\text { per } \\
\text { shoot } \|\end{array}$ & $\begin{array}{l}\text { Number of } \\
\text { panicles } \\
\text { per culture }\end{array}$ & $\begin{array}{c}\text { Number of } \\
\text { panicles } \\
\text { per plant }\end{array}$ & $\begin{array}{l}\text { Dry weight } \\
\text { of panicles } \\
\text { per culture }\end{array}$ & $\begin{array}{c}\text { Dry weight } \\
\text { per } \\
\text { panicle }\end{array}$ \\
\hline $\begin{array}{c}c m \\
70.1\end{array}$ & $\begin{array}{c}g m \\
20.60\end{array}$ & $\begin{array}{l}g m \\
2.17\end{array}$ & 0.0 & 0.00 & $\begin{array}{c}g m \\
0.00\end{array}$ & $\begin{array}{c}g m \\
0.00\end{array}$ \\
\hline 69.5 & 16.60 & 2.77 & 0.0 & 0.00 & 0.00 & 0.00 \\
\hline 15.0 & 1.05 & 0.70 & 0.0 & 0.00 & 0.00 & 0.00 \\
\hline 0.0 & 0.00 & 0.00 & 0.0 & 0.00 & 0.00 & 0.00 \\
\hline 73.5 & 23.15 & 2.57 & 2.5 & 0.28 & 1.95 & 0.74 \\
\hline 76.0 & 22.15 & 2.33 & 0.5 & 0.05 & 0.25 & 0.50 \\
\hline 70.0 & 24.95 & 3.12 & 1.0 & 0.13 & 1.25 & 1.25 \\
\hline 66.0 & 22.20 & 2.02 & 1.5 & 0.14 & 0.60 & 0.40 \\
\hline 57.0 & 15.00 & 1.58 & 2.0 & 0.21 & 0.15 & 0.08 \\
\hline 28.5 & 4.25 & 0.94 & 0.0 & 0.00 & 0.00 & 0.00 \\
\hline 87.0 & 28.60 & 2.60 & 7.0 & 0.64 & 6.00 & 0.86 \\
\hline 83.5 & 22.60 & 2.88 & 1.9 & 0.24 & 2.00 & 1.05 \\
\hline 91.5 & 29.40 & 2.94 & 6.5 & 0.65 & 5.60 & 0.86 \\
\hline 84.0 & 28.70 & 2.50 & 6.0 & 0.52 & 3.40 & 0.57 \\
\hline 68.0 & 10.30 & 1.14 & 0.5 & 0.06 & 0.25 & 0.50 \\
\hline 41.0 & 10.30 & 1.47 & 0.0 & 0.00 & 0.00 & 0.00 \\
\hline 82.0 & 30.25 & 2.33 & 7.0 & 0.54 & 4.50 & 0.64 \\
\hline 79.0 & 30.70 & 2.46 & 5.0 & 0.40 & 2.95 & 0.59 \\
\hline 85.0 & 32.50 & 3.25 & 3.0 & 0.30 & 3.05 & 1.02 \\
\hline 88.0 & 30.70 & 2.92 & 2.5 & 0.24 & 3.20 & 1.28 \\
\hline 80.0 & 12.90 & 1.36 & 2.0 & 0.21 & 1.85 & 0.93 \\
\hline 61.5 & 12.90 & 2.35 & 0.5 & 0.09 & 0.20 & 0.40 \\
\hline 90.5 & 30.00 & 2.73 & 5.0 & 0.45 & 3.15 & 0.63 \\
\hline 91.5 & 30.00 & 2.73 & 0.5 & 0.05 & 0.15 & 0.30 \\
\hline 88.0 & 22.25 & 2.23 & 5.5 & 0.55 & 4.50 & 0.82 \\
\hline 75.0 & 21.50 & 2.26 & 8.0 & 0.84 & 3.80 & 0.48 \\
\hline 78.0 & 23.25 & 2.33 & 5.5 & 0.55 & 4.80 & 0.87 \\
\hline 80.5 & 24.60 & 1.97 & 7.0 & 0.56 & 7.20 & 1.03 \\
\hline 74.5 & 31.10 & 2.59 & 13.0 & 1.08 & 6.50 & 0.50 \\
\hline 74.5 & 31.10 & 2.22 & 15.5 & 1.11 & 8.90 & 0.57 \\
\hline 79.5 & 27.20 & 3.02 & 4.5 & 0.50 & 3.65 & 0.81 \\
\hline 80.0 & 21.90 & 1.99 & 11.0 & 1.00 & 7.65 & 0.70 \\
\hline 80.0 & 21.10 & 1.62 & 6.5 & 0.50 & 9.50 & 1.46 \\
\hline 80.0 & 25.15 & 2.19 & 3.0 & 0.26 & 1.05 & 0.35 \\
\hline 86.5 & 30.70 & 3.07 & 6.0 & 0.60 & 3.05 & 0.51 \\
\hline 77.0 & 29.05 & 2.32 & 10.5 & 0.84 & 4.75 & 0.45 \\
\hline 71.5 & 26.75 & 2.18 & 13.1 & 1.07 & 8.99 & 0.69 \\
\hline
\end{tabular}

$\ddagger$ Based upon an average of two replicates per treatment.

Data were obtained when plants were mature (dry) and harvested (134 days after planting) with the exception of data on morphologic aberrations.

U Shoot includes stems, leaves, and panicles collectively. 
TABLE 4

RESPONSE OF DRILLED AND SOWN RICE TO SODIUM MCP APPLIED

NoTE: The following is a key to the aberration indices for rice in column 5 :

$1=$ excessive numbers of massive adventitious roots at base of shoot.

$2=$ base of shoot swollen due to presence of proliferating adventitious root and stem tissue.

$3=$ twisting or curvature of elongating internodes.

$4=$ accelerated elongation of internodes.

$5=$ proliferation of axillary buds (young tiller shoots) at base of parent shoot.

$6=$ aberrant emergence of young inner leaves from sheaths of older leaves, i.e., buckling out.

Numbers in boldface in the column indicate that the symptom was

\begin{tabular}{|c|c|c|c|c|c|}
\hline \multicolumn{6}{|c|}{ TREATMENT } \\
\hline Method of planting & $\begin{array}{l}\text { Age of plants } \\
\text { at treatment } \\
\text { time }\end{array}$ & $\begin{array}{c}\text { Method of } \\
\text { application of } \\
\text { sodium MCP }\end{array}$ & $\begin{array}{l}\text { Pounds acid } \\
\text { equivalent per } \\
\text { acre applied }\end{array}$ & Aberration indices for rice & $\begin{array}{c}\text { Number of } \\
\text { plants per } \\
\text { culture* }\end{array}$ \\
\hline Sown & $\begin{array}{c}\text { days } \\
13 \\
13 \\
13 \\
13 \\
15 \\
15\end{array}$ & $\begin{array}{l}\text { water } \\
\text { water } \\
\text { water } \\
\text { water } \\
\text { foliage } \\
\text { foliage }\end{array}$ & $\begin{array}{r}1.5 \\
3.0 \\
6.0 \\
12.0 \\
1.5 \\
3.0\end{array}$ & $\begin{array}{l}1,2,4,11 \\
1,2,4,6,10,11 \\
1,2,4,6,8,10,11,12 \\
2,6,8,10,11,12 \\
1,2,4,9,11 \\
1,2,4,7,10,11\end{array}$ & $\begin{array}{r}10.0 \\
3.5 \\
1.0 \\
1.0 \\
11.0 \\
9.0\end{array}$ \\
\hline Drilled & $\begin{array}{l}13 \\
13 \\
13 \\
13 \\
15 \\
15\end{array}$ & $\begin{array}{l}\text { water } \\
\text { water } \\
\text { water } \\
\text { water } \\
\text { foliage } \\
\text { foliage }\end{array}$ & $\begin{array}{r}1.5 \\
3.0 \\
6.0 \\
12.0 \\
1.5 \\
3.0\end{array}$ & $\begin{array}{l}1,2,4,11 \\
1,2,4,7,8,10,11 \\
1,2,4,6,8,10,11 \\
2,6,8,10,11,12 \\
13 \\
1,2,4,7,9\end{array}$ & $\begin{array}{r}9.5 \\
6.0 \\
4.5 \\
1.0 \\
9.5 \\
12.0\end{array}$ \\
\hline Sown & $\begin{array}{l}28 \\
28 \\
28 \\
28 \\
28 \\
28\end{array}$ & $\begin{array}{l}\text { water } \\
\text { water } \\
\text { water } \\
\text { water } \\
\text { foliage } \\
\text { foliage }\end{array}$ & $\begin{array}{r}1.5 \\
3.0 \\
6.0 \\
12.0 \\
1.5 \\
3.0\end{array}$ & $\begin{array}{l}1,2,4,11 \\
1,2,4,11 \\
1,2,4,11 \\
1,2,4,5,11 \\
1,2,4 \\
1,2,4,11\end{array}$ & $\begin{array}{l}13.0 \\
11.5 \\
12.0 \\
10.5 \\
13.5 \\
12.0\end{array}$ \\
\hline Drilled & $\begin{array}{l}28 \\
28 \\
28 \\
28 \\
28 \\
28\end{array}$ & $\begin{array}{l}\text { water } \\
\text { water } \\
\text { water } \\
\text { water } \\
\text { foliage } \\
\text { foliage }\end{array}$ & $\begin{array}{r}1.5 \\
3.0 \\
6.0 \\
12.0 \\
1.5 \\
3.0\end{array}$ & $\begin{array}{l}1,2,4 \\
1,2,4,11 \\
1,2,4,11 \\
1,2,4,10,11 \\
1,2,4 \\
1,2,4\end{array}$ & $\begin{array}{r}9.0 \\
6.0 \\
9.0 \\
8.0 \\
10.0 \\
10.0\end{array}$ \\
\hline Sown & $\begin{array}{l}46 \\
46 \\
46 \\
46 \\
46 \\
46\end{array}$ & $\begin{array}{l}\text { water } \\
\text { water } \\
\text { water } \\
\text { water } \\
\text { foliage } \\
\text { foliage }\end{array}$ & $\begin{array}{r}1.5 \\
3.0 \\
6.0 \\
12.0 \\
1.5 \\
3.0\end{array}$ & $\begin{array}{l}1,4 \\
1,2,4 \\
2,4,9 \\
2,4,9 \\
1,4 \\
1,2,4\end{array}$ & \begin{tabular}{l|}
13.0 \\
10.0 \\
11.0 \\
10.5 \\
12.0 \\
11.0
\end{tabular} \\
\hline Drilled & $\begin{array}{l}46 \\
46 \\
46 \\
46 \\
46 \\
46\end{array}$ & $\begin{array}{l}\text { water } \\
\text { water } \\
\text { water } \\
\text { water } \\
\text { foliage } \\
\text { foliage }\end{array}$ & $\begin{array}{r}1.5 \\
3.0 \\
6.0 \\
12.0 \\
1.5 \\
3.0\end{array}$ & $\begin{array}{l}1,4 \\
2 \\
2 \\
2 \\
1,4 \\
1,2,4\end{array}$ & $\begin{array}{r}8.5 \\
11.0 \\
9.5 \\
9.0 \\
15.0 \\
13.0\end{array}$ \\
\hline Sown... & .. & $\ldots \ldots$ & control $\dagger$ & 13 & 12.3 \\
\hline
\end{tabular}

* Initial number of plants per culture varied from 10 to 15 .

$\dagger$ Based upon an average of 11 control replicates. 


\section{TABLE 4}

\section{AT SEVERAL DOSAGES TO WATER AND FOLIAGE AT THREE DATES}

$7=$ twisted and tubular leaves.

$8=$ precocious yellowing of leaves.

$9=$ presence of exceptionally tall leaves due to stimulated leaf elongation.

$10=$ reduced height of shoots due to premature leaf and internode maturation.

$11=$ shoots lodged due to weak and excessively elongated internodes.

$12=$ entire plant dead.

$13=$ vegetative plants expressing no aberrations.

more intense than the others listed for that particular treatment.

\begin{tabular}{|c|c|c|c|c|c|c|}
\hline \multicolumn{7}{|c|}{ RESULTS $\$ \S$} \\
\hline $\begin{array}{l}\text { Average height } \\
\text { of plants } \\
\text { per culture }\end{array}$ & $\begin{array}{c}\text { Dry weight } \\
\text { of shoots\| } \\
\text { per culture }\end{array}$ & $\begin{array}{c}\text { Dry weight } \\
\text { per } \\
\text { shoot\| }\end{array}$ & $\begin{array}{c}\text { Number of } \\
\text { panicles } \\
\text { per culture }\end{array}$ & $\begin{array}{l}\text { Number of } \\
\text { panicles } \\
\text { per plant }\end{array}$ & $\begin{array}{l}\text { Dry weight } \\
\text { of panicles } \\
\text { per culture }\end{array}$ & $\begin{array}{c}\text { Dry weight } \\
\text { per } \\
\text { panicle }\end{array}$ \\
\hline $\begin{array}{c}\mathrm{cm} \\
68.0\end{array}$ & $\begin{array}{c}g m \\
21.69\end{array}$ & $\begin{array}{l}g m \\
2.17\end{array}$ & 7.0 & 0.70 & $\begin{array}{c}g m \\
1.06\end{array}$ & $\begin{array}{c}g m \\
0.15\end{array}$ \\
\hline 40.0 & 3.85 & 1.10 & 0.5 & 0.14 & 0.35 & 0.70 \\
\hline 11.0 & 0.60 & 0.60 & 0.0 & 0.00 & 0.00 & 0.00 \\
\hline 5.0 & 0.20 & 0.20 & 0.0 & 0.00 & 0.00 & 0.00 \\
\hline 98.0 & 33.25 & 3.02 & 6.5 & 0.59 & 3.50 & 0.54 \\
\hline 93.0 & 23.30 & 2.59 & 4.0 & 0.44 & 4.60 & 1.15 \\
\hline 82.5 & 25.65 & 2.70 & 3.5 & 0.37 & 1.66 & 0.47 \\
\hline 42.0 & 4.85 & 0.81 & 3.0 & 0.50 & 0.30 & 0.10 \\
\hline 32.0 & 2.85 & 0.63 & 0.5 & 0.11 & 0.05 & 0.10 \\
\hline 8.0 & 0.60 & 0.60 & 0.0 & 0.00 & 0.00 & 0.00 \\
\hline 78.5 & 26.90 & 2.83 & 9.5 & 0.10 & 8.30 & 0.87 \\
\hline 90.0 & 26.70 & 2.23 & 8.5 & 0.19 & 9.40 & 1.11 \\
\hline 78.5 & 24.75 & 1.90 & 11.5 & 0.88 & 7.80 & 0.68 \\
\hline 73.0 & 24.60 & 2.14 & 9.5 & 0.83 & 2.75 & 0.29 \\
\hline 73.5 & 19.75 & 1.66 & 10.0 & 0.83 & 2.90 & 0.29 \\
\hline 67.5 & 15.00 & 1.48 & 8.5 & 0.81 & 1.05 & 0.12 \\
\hline 92.0 & 31.50 & 2.33 & 8.0 & 0.59 & 2.85 & 0.36 \\
\hline 82.0 & 30.55 & 2.55 & 10.0 & 0.85 & 4.65 & 0.47 \\
\hline 97.0 & 23.65 & 2.63 & 4.5 & 0.50 & 7.60 & 1.69 \\
\hline 93.5 & 21.55 & 3.59 & 5.0 & 0.83 & 3.30 & 0.55 \\
\hline 80.5 & 21.75 & 2.42 & 6.5 & 0.72 & 2.05 & 0.32 \\
\hline 66.5 & 12.80 & 1.60 & 2.0 & 0.25 & 0.50 & 0.25 \\
\hline 88.5 & 31.80 & 3.18 & 2.5 & 0.25 & 2.45 & 0.94 \\
\hline 94.5 & 30.40 & 3.04 & 2.0 & 0.20 & 1.80 & 0.90 \\
\hline 64.5 & 23.75 & 1.83 & 14.0 & 1.08 & 7.80 & 0.56 \\
\hline 79.5 & 23.55 & 2.36 & 11.0 & 1.10 & 8.80 & 0.80 \\
\hline 78.0 & 23.00 & 2.09 & 9.0 & 0.82 & 5.52 & 0.61 \\
\hline 80.5 & 23.70 & 2.26 & 7.5 & 0.71 & 4.25 & 0.57 \\
\hline 85.5 & 26.10 & 2.18 & 8.0 & 0.67 & 6.10 & 0.76 \\
\hline 75.5 & 28.10 & 2.56 & 15.0 & 1.36 & 6.00 & 0.40 \\
\hline 85.5 & 12.55 & 1.48 & 5.5 & 0.65 & 6.45 & 1.17 \\
\hline 83.5 & 24.15 & 2.19 & 9.0 & 0.82 & 7.05 & 0.78 \\
\hline 75.5 & 22.30 & 2.35 & 6.5 & 0.68 & 2.65 & 0.41 \\
\hline 68.5 & 21.65 & 2.41 & 3.0 & 0.33 & 0.90 & 0.30 \\
\hline 75.0 & 29.90 & 0.20 & 9.0 & 0.60 & 4.75 & 0.53 \\
\hline 77.0 & 31.55 & 2.43 & 9.5 & 0.73 & 3.90 & 0.41 \\
\hline 71.5 & 26.75 & 2.18 & 13.1 & 1.07 & 8.99 & 0.69 \\
\hline
\end{tabular}

Based upon an average of two replicates per treatment.

Data were obtained when plants were mature (dry) and harvested (134 days after planting) with the exception of data on morphologic aberrations.

|| Shoot includes stems, leaves, and panicles collectively. 
TABLE 5

RESPONSE OF DRILLED AND SOWN RICE TO AMINE MCP AT

NотE: The following is a key to the aberration indices for rice in column 5 :

$1=$ excessive numbers of massive adventitious roots at base of shoot.

$2=$ base of shoot swollen due to presence of proliferating adventitiou, root and stem tissue.

$3=$ twisting or curvature of elongating internodes.

$4=$ accelerated elongation of internodes.

$5=$ proliferation of axillary buds (young tiller shoots) at base of parent shoot.

$6=$ aberrant emergence of young inner leaves from sheaths of older leaves, i.e., buckling out.

Numbers in boldface in the column indicate that the symptom was

\begin{tabular}{|c|c|c|c|c|c|}
\hline \multicolumn{6}{|c|}{ TREATMENT } \\
\hline Method of planting & $\begin{array}{l}\text { Age of plants } \\
\text { at treatment } \\
\text { time }\end{array}$ & $\begin{array}{c}\text { Method of } \\
\text { application of } \\
\text { amine MCP }\end{array}$ & $\begin{array}{l}\text { Pounds acid } \\
\text { equivalent per } \\
\text { acre applied }\end{array}$ & Aberration indices for rice & $\begin{array}{l}\text { Number of } \\
\text { plants per } \\
\text { culture* }\end{array}$ \\
\hline Sown & $\begin{array}{c}\text { days } \\
13 \\
13 \\
13 \\
13\end{array}$ & $\begin{array}{l}\text { water } \\
\text { water } \\
\text { water } \\
\text { water }\end{array}$ & $\begin{array}{r}1.5 \\
3.0 \\
6.0 \\
12.0\end{array}$ & $\begin{array}{l}1,2,3,4,8,11 \\
1,2,4,6,8,11 \\
1,2,4,6,8,11,12 \\
2,6,8,10,11,12\end{array}$ & $\begin{array}{l}7.5 \\
3.5 \\
4.0 \\
0.0\end{array}$ \\
\hline Drilled & $\begin{array}{l}13 \\
13 \\
13 \\
13\end{array}$ & $\begin{array}{l}\text { water } \\
\text { water } \\
\text { water } \\
\text { water }\end{array}$ & $\begin{array}{r}1.5 \\
3.0 \\
6.0 \\
12.0\end{array}$ & $\begin{array}{l}1,2,4,8,11 \\
1,2,4,6,8,11 \\
1,2,4,6,8,11,12,15 \\
1,2,3,4,6,7,8,10,11,12\end{array}$ & $\begin{array}{r}10.0 \\
8.5 \\
5.0 \\
2.5\end{array}$ \\
\hline Sown & $\begin{array}{l}28 \\
28 \\
28 \\
28\end{array}$ & $\begin{array}{l}\text { water } \\
\text { water } \\
\text { water } \\
\text { water }\end{array}$ & $\begin{array}{r}1.5 \\
3.0 \\
6.0 \\
12.0\end{array}$ & $\begin{array}{l}1,2,4,11 \\
1,2,4,11 \\
1,2,4,11 \\
1,2,4,6,10,11\end{array}$ & $\begin{array}{r}11.0 \\
12.0 \\
12.5 \\
8.5\end{array}$ \\
\hline Drilled & $\begin{array}{l}28 \\
28 \\
28 \\
28\end{array}$ & $\begin{array}{l}\text { water } \\
\text { water } \\
\text { water } \\
\text { water }\end{array}$ & $\begin{array}{r}1.5 \\
3.0 \\
6.0 \\
12.0\end{array}$ & $\begin{array}{l}1,2,4 \\
1,2,4 \\
1,2,4,11 \\
1,2,4,5,6,11\end{array}$ & $\begin{array}{r}9.5 \\
11.0 \\
10.0 \\
6.0\end{array}$ \\
\hline Sown & $\begin{array}{l}46 \\
46 \\
46 \\
46\end{array}$ & $\begin{array}{l}\text { water } \\
\text { water } \\
\text { water } \\
\text { water }\end{array}$ & $\begin{array}{r}1.5 \\
3.0 \\
6.0 \\
12.0\end{array}$ & $\begin{array}{l}1,4,9 \\
1,2,4 \\
1,4 \\
1,2,4\end{array}$ & $\begin{array}{l}13.5 \\
11.0 \\
11.0 \\
11.0\end{array}$ \\
\hline Drilled & $\begin{array}{l}46 \\
46 \\
46 \\
46\end{array}$ & $\begin{array}{l}\text { water } \\
\text { water } \\
\text { water } \\
\text { water }\end{array}$ & $\begin{array}{r}1.5 \\
3.0 \\
6.0 \\
12.0\end{array}$ & $\begin{array}{l}1,2 \\
2,9 \\
2 \\
2,4\end{array}$ & $\begin{array}{r}7.5 \\
9.0 \\
11.0 \\
7.5\end{array}$ \\
\hline Sown............. & . & $\ldots \ldots$ & control† & 13 & 12.3 \\
\hline
\end{tabular}

* Initial number of plants per culture varied from 10 to 15 .

$\dagger$ Based upon an average of 11 control replicates. 
TABLE 5

$7=$ twisted and tubular leaves.

$8=$ precocious yellowing of leaves.

$9=$ presence of exceptionally tall leaves due to stimulated leaf elongation.

$10=$ reduced height of shoots due to premature leaf and internode maturation.

$11=$ shoots lodged due to weak and excessively elongated internodes.

$12=$ entire plant dead.

$13=$ vegetative plants expressing no aberrations.

more intense than the others listed for that particular treatment.

\begin{tabular}{|c|c|c|c|c|c|c|}
\hline \multicolumn{7}{|c|}{ RESULTS $\ddagger \S$} \\
\hline $\begin{array}{l}\text { Average height } \\
\text { of plants } \\
\text { per culture }\end{array}$ & $\begin{array}{c}\text { Dry weight } \\
\text { of shoots\| } \\
\text { per culture }\end{array}$ & $\begin{array}{c}\text { Dry weight } \\
\text { per } \\
\text { shoot } \|\end{array}$ & $\begin{array}{l}\text { Number of } \\
\text { panicles } \\
\text { per culture }\end{array}$ & $\begin{array}{c}\text { Number of } \\
\text { panicles } \\
\text { per plant }\end{array}$ & $\begin{array}{l}\text { Dry weight } \\
\text { of panicles } \\
\text { per culture }\end{array}$ & $\begin{array}{c}\text { Dry weight } \\
\text { per } \\
\text { panicle }\end{array}$ \\
\hline $\begin{array}{c}c m \\
67.0\end{array}$ & $\begin{array}{c}g m \\
16.80\end{array}$ & $\begin{array}{l}g m \\
2.24\end{array}$ & 2.0 & 0.27 & $\begin{array}{c}g m \\
1.85\end{array}$ & $\begin{array}{c}g m \\
0.93\end{array}$ \\
\hline 40.5 & 4.35 & 1.24 & 1.5 & 0.43 & 1.17 & 0.78 \\
\hline 35.0 & 5.30 & 1.33 & 1.5 & 0.38 & 0.75 & 0.19 \\
\hline 0.0 & 0.00 & 0.00 & 0.0 & 0.00 & 0.00 & 0.00 \\
\hline 77.0 & 24.69 & 2.47 & 6.0 & 0.60 & 7.10 & 0.71 \\
\hline 55.0 & 12.05 & 1.42 & 6.5 & 0.76 & 4.50 & 0.69 \\
\hline 29.0 & 2.65 & 0.53 & 0.5 & 0.10 & 0.10 & 0.02 \\
\hline 15.0 & 0.90 & 0.36 & 0.0 & 0.00 & 0.00 & 0.00 \\
\hline 82.5 & 23.50 & 2.14 & 8.5 & 0.77 & 8.95 & 1.05 \\
\hline 77.0 & 26.90 & 2.24 & 8.0 & 0.67 & 2.10 & 0.24 \\
\hline 68.5 & 20.75 & 1.66 & 9.0 & 0.72 & 2.00 & 0.22 \\
\hline 62.5 & 12.25 & 1.44 & 6.0 & 0.71 & 0.80 & 0.13 \\
\hline 95.0 & 32.35 & 3.41 & 5.0 & 0.53 & 4.00 & 0.80 \\
\hline 88.5 & 26.25 & 2.39 & 8.5 & 0.77 & 6.10 & 0.72 \\
\hline 76.0 & 20.50 & 2.05 & 7.0 & 0.70 & 2.75 & 0.39 \\
\hline 65.5 & 12.25 & 2.04 & 1.5 & 0.25 & 0.55 & 0.37 \\
\hline 74.0 & 22.25 & 1.65 & 12.0 & 0.89 & 7.85 & 6.54 \\
\hline 72.5 & 21.45 & 1.95 & 10.0 & 0.91 & 7.00 & 0.70 \\
\hline 78.0 & 22.35 & 2.03 & 9.5 & 0.86 & 6.75 & 0.71 \\
\hline 82.0 & 20.25 & 1.93 & 7.5 & 0.68 & 5.75 & 0.77 \\
\hline 82.5 & 24.05 & 3.21 & 6.0 & 0.80 & 5.60 & 0.93 \\
\hline 80.0 & 26.65 & 2.96 & 5.0 & 0.56 & 3.60 & 0.72 \\
\hline 83.5 & 26.50 & 2.41 & 8.0 & 0.73 & 2.70 & 0.34 \\
\hline 75.5 & 21.60 & 2.88 & 4.0 & 0.53 & 1.10 & 0.28 \\
\hline 71.5 & 26.75 & 2.18 & 13.1 & 1.07 & 8.99 & 0.69 \\
\hline
\end{tabular}

$\ddagger$ Based upon an average of two replicates per treatment.

Data were obtained when plants were mature (dry) and harvested (134 days after planting) with the exception of data on morphologic aberrations.

\| Shoot includes stems, leaves, and panicles collectively. 
TABLE 6

RESPONSE OF DRILLED AND SOWN RICE TO AMINE 2,4,5-T AT

NoTE: The following is a key to the aberration indices for rice in column 5 :

$1=$ excessive numbers of massive adventitious roots at base of shoot.

$2=$ base of shoot swollen due to presence of proliferating adventitious root and stem tissue.

$3=$ twisting or curvature of elongating internodes.

$4=$ accelerated elongation of internodes.

$5=$ proliferation of axillary buds (young tiller shoots) at base of parent shoot.

$6=$ aberrant emergence of young inner leaves from sheaths of older leaves, i.e., buckling out.

\begin{tabular}{|c|c|c|c|c|c|}
\hline \multicolumn{6}{|c|}{ TREATMENT } \\
\hline Method of planting & $\begin{array}{l}\text { Age of plants } \\
\text { at treatment } \\
\text { time }\end{array}$ & $\begin{array}{l}\text { Method of } \\
\text { application } \\
\text { of } 2,4,5-T\end{array}$ & $\begin{array}{l}\text { Pounds acid } \\
\text { equivalent per } \\
\text { acre applied }\end{array}$ & Aberration indices for rice & $\begin{array}{c}\text { Number of } \\
\text { plants per } \\
\text { culture* }\end{array}$ \\
\hline Sown & $\begin{array}{c}\text { days } \\
13 \\
13 \\
13 \\
13 \\
15 \\
15\end{array}$ & $\begin{array}{l}\text { water } \\
\text { water } \\
\text { water } \\
\text { water } \\
\text { foliage } \\
\text { foliage }\end{array}$ & $\begin{array}{r}1.5 \\
3.0 \\
6.0 \\
12.0 \\
1.5 \\
3.0\end{array}$ & $\begin{array}{l}1,2,4,8,11 \\
1,2,3,4,11 \\
1,2,4,6,11 \\
1,2,4,6,8,11 \\
1,2,4,11 \\
1,2,4,11\end{array}$ & $\begin{array}{r}9.5 \\
9.0 \\
8.0 \\
8.0 \\
10.5 \\
10.5\end{array}$ \\
\hline Drilled & $\begin{array}{l}13 \\
13 \\
13 \\
13 \\
15 \\
15\end{array}$ & $\begin{array}{l}\text { water } \\
\text { water } \\
\text { water } \\
\text { water } \\
\text { foliage } \\
\text { foliage }\end{array}$ & $\begin{array}{r}1.5 \\
3.0 \\
6.0 \\
12.0 \\
1.5 \\
3.0\end{array}$ & $\begin{array}{l}1,4 \\
1,2,4,8,11 \\
1,2,4,6,11 \\
1,2,4,6,8,11 \\
13 \\
4\end{array}$ & $\begin{array}{r}10.0 \\
10.5 \\
8.0 \\
8.5 \\
10.0 \\
9.5\end{array}$ \\
\hline Sown & $\begin{array}{l}28 \\
28 \\
28 \\
28 \\
28 \\
28\end{array}$ & $\begin{array}{l}\text { water } \\
\text { water } \\
\text { water } \\
\text { water } \\
\text { foliage } \\
\text { foliage }\end{array}$ & $\begin{array}{r}1.5 \\
3.0 \\
6.0 \\
12.0 \\
1.5 \\
3.0\end{array}$ & $\begin{array}{l}1,2,4 \\
1,2,4 \\
1,2,4,8,11 \\
1,2,4,8,11 \\
1,2,4 \\
1,2,4,7,8\end{array}$ & $\begin{array}{l}14.0 \\
12.5 \\
13.5 \\
12.5 \\
11.5 \\
11.0\end{array}$ \\
\hline Drilled & $\begin{array}{l}28 \\
28 \\
28 \\
28 \\
28 \\
28\end{array}$ & $\begin{array}{l}\text { water } \\
\text { water } \\
\text { water } \\
\text { water } \\
\text { foliage } \\
\text { foliage }\end{array}$ & $\begin{array}{r}1.5 \\
3.0 \\
6.0 \\
12.0 \\
1.5 \\
3.0\end{array}$ & $\begin{array}{l}1,4 \\
1,2 \\
1,2,4,8 \\
1,2,4,8,11 \\
1,6 \\
1,2,4,7\end{array}$ & $\begin{array}{l}13.5 \\
13.5 \\
11.5 \\
12.0 \\
12.0 \\
11.0\end{array}$ \\
\hline Sown & $\begin{array}{l}46 \\
46 \\
46 \\
46 \\
46 \\
46\end{array}$ & $\begin{array}{l}\text { water } \\
\text { water } \\
\text { water } \\
\text { water } \\
\text { foliage } \\
\text { foliage }\end{array}$ & $\begin{array}{r}1.5 \\
3.0 \\
6.0 \\
12.0 \\
1.5 \\
3.0\end{array}$ & $\begin{array}{l}1 \\
1 \\
4,7 \\
1,2,4,7,11 \\
1,4 \\
1,2\end{array}$ & $\begin{array}{l}11.5 \\
11.0 \\
12.5 \\
11.5 \\
13.5 \\
15.0\end{array}$ \\
\hline Drilled & $\begin{array}{l}46 \\
46 \\
46 \\
46 \\
46 \\
46\end{array}$ & $\begin{array}{l}\text { water } \\
\text { water } \\
\text { water } \\
\text { water } \\
\text { foliage } \\
\text { foliage }\end{array}$ & $\begin{array}{r}1.5 \\
3.0 \\
6.0 \\
12.0 \\
1.5 \\
3.0\end{array}$ & $\begin{array}{l}13 \\
13 \\
13 \\
2,4 \\
1,4 \\
1,2\end{array}$ & $\begin{array}{r}9.0 \\
10.5 \\
9.0 \\
11.0 \\
14.0 \\
13.0\end{array}$ \\
\hline Sown $\ldots \ldots \ldots \ldots$ & .. & $\ldots \ldots$ & control $\dagger$ & 13 & 12.3 \\
\hline
\end{tabular}

* Initial number of plants per culture varied from 10 to 15 .

$\dagger$ Based upon an average of 11 control replicates. 


\section{TABLE 6}

\section{SEVERAL DOSAGES APPLIED TO WATER AND FOLIAGE AT THREE DATES}

$7=$ twisted and tubular leaves.

$8=$ precocious yellowing of leaves.

$9=$ presence of exceptionally tall leaves due to stimulated leaf elongation.

$10=$ reduced height of shoots due to premature leaf and internode maturation.

$11=$ shoots lodged due to weak and excessively elongated internodes.

$12=$ entire plant dead.

13 = vegetative plants expressing no aberrations.

\begin{tabular}{|c|c|c|c|c|c|c|}
\hline \multicolumn{7}{|c|}{ RESULTS $\$ \S$} \\
\hline $\begin{array}{l}\text { Average height } \\
\text { of plants } \\
\text { per culture }\end{array}$ & $\begin{array}{c}\text { Dry weight } \\
\text { of shoots\| } \\
\text { per culture }\end{array}$ & $\begin{array}{c}\text { Dry weight } \\
\text { per } \\
\text { shoot } \|\end{array}$ & $\begin{array}{c}\text { Number of } \\
\text { panicles } \\
\text { per culture }\end{array}$ & $\begin{array}{c}\text { Number of } \\
\text { panicles } \\
\text { per plant }\end{array}$ & $\begin{array}{l}\text { Dry weight } \\
\text { of panicles } \\
\text { per culture }\end{array}$ & $\begin{array}{c}\text { Dry weight } \\
\text { per } \\
\text { panicle }\end{array}$ \\
\hline $\begin{array}{c}\mathrm{cm} \\
81.0\end{array}$ & $\begin{array}{c}g m \\
24.35\end{array}$ & $\begin{array}{l}g m \\
2.56\end{array}$ & 0.0 & 0.00 & $\begin{array}{c}g m \\
0.00\end{array}$ & $\begin{array}{c}g m \\
0.00\end{array}$ \\
\hline 87.0 & 27.70 & 3.08 & 0.5 & 0.05 & 0.55 & 1.10 \\
\hline 85.0 & 23.65 & 2.96 & 1.5 & 0.19 & 1.35 & 0.90 \\
\hline 66.5 & 11.65 & 1.46 & 1.0 & 0.13 & 0.55 & 0.55 \\
\hline 82.0 & 28.00 & 2.67 & 8.5 & 0.81 & 7.70 & 0.91 \\
\hline 88.0 & 28.90 & 2.75 & 6.5 & 0.62 & 3.40 & 0.52 \\
\hline 75.5 & 27.95 & 2.80 & 1.0 & 0.10 & 0.45 & 0.45 \\
\hline 84.0 & 31.80 & 3.03 & 3.0 & 0.29 & 2.25 & 0.75 \\
\hline 82.0 & 29.05 & 3.63 & 1.0 & 0.13 & 1.50 & 1.50 \\
\hline 72.5 & 17.40 & 2.05 & 1.0 & 0.12 & 1.05 & 1.05 \\
\hline 82.0 & 29.15 & 2.92 & 10.5 & 1.05 & 12.30 & 1.17 \\
\hline 87.0 & 28.95 & 3.05 & 7.5 & 0.79 & 4.60 & 0.61 \\
\hline 84.5 & 29.35 & 2.10 & 10.0 & 0.71 & 6.45 & 0.65 \\
\hline 87.5 & 23.95 & 1.92 & 9.5 & 0.79 & 9.95 & 1.05 \\
\hline 83.5 & 28.25 & 2.09 & 6.5 & 0.48 & 3.65 & 0.56 \\
\hline 74.0 & 22.15 & 1.82 & 9.5 & 0.76 & 3.30 & 0.35 \\
\hline 94.0 & 31.01 & 2.69 & 7.0 & 0.61 & 3.40 & 0.49 \\
\hline 90.0 & 31.75 & 2.89 & 6.0 & 0.56 & 3.45 & 0.58 \\
\hline 88.0 & 26.80 & 1.99 & 10.0 & 0.74 & 6.10 & 0.61 \\
\hline 89.5 & 27.65 & 2.05 & 10.0 & 0.74 & 5.95 & 0.60 \\
\hline 84.5 & 24.20 & 2.10 & 6.0 & 0.52 & 3.55 & 0.69 \\
\hline 84.0 & 24.45 & 2.04 & 3.0 & 0.25 & 1.00 & 0.33 \\
\hline 79.5 & 29.50 & 2.46 & 10.0 & 0.83 & 5.95 & 0.60 \\
\hline 89.5 & 29.50 & 2.68 & 3.5 & 0.32 & 2.15 & 0.61 \\
\hline 73.5 & 22.20 & 1.93 & 11.5 & 1.00 & 14.70 & 1.28 \\
\hline 80.0 & 24.45 & 2.22 & 10.5 & 0.96 & 6.35 & 0.60 \\
\hline 81.0 & 21.80 & 1.74 & 12.5 & 1.00 & 9.40 & 0.75 \\
\hline 73.5 & 22.40 & 1.95 & 4.5 & 0.39 & 1.55 & 0.34 \\
\hline 78.5 & 31.70 & 2.35 & 10.5 & 0.78 & 5.10 & 0.49 \\
\hline 80.5 & 30.40 & 2.03 & 13.0 & 0.87 & 5.65 & 0.43 \\
\hline 75.5 & 26.30 & 2.92 & 13.0 & 1.44 & 9.45 & 0.73 \\
\hline 76.0 & 24.05 & 2.29 & 12.0 & 1.14 & 8.65 & 0.72 \\
\hline 74.5 & 25.10 & 2.79 & 7.5 & 0.83 & 5.00 & 0.67 \\
\hline 77.0 & 24.40 & 2.22 & 8.5 & 0.77 & 3.55 & 0.42 \\
\hline 75.0 & 30.90 & 2.21 & 5.0 & 0.36 & 3.15 & 0.63 \\
\hline 78.0 & 29.80 & 2.29 & 13.5 & 1.04 & 3.60 & 0.27 \\
\hline 71.5 & 26.75 & 2.18 & 13.1 & 1.07 & 8.99 & 0.69 \\
\hline
\end{tabular}

Based upon an average of two replicates per treatment.

Data were obtained when plants were mature (dry) and harvested (134 days after planting) with the exception of dsta on morphologic aberrations.

|| Shoot includes stems, leaves, and panicles collectively. 


\section{TABLE 7}

RESPONSE OF RICE AND SEVERAL AQUATIC WEEDS TO PELLETED SEVERAL DOSAGES TO WATER IN

NoтE: The following is a key to the abberation indices for rice in column 4 and for weeds in the last column.

$1=$ excessive numbers of massive adventitious roots at base of shoot.

$2=$ base of shoot swollen due to presence of proliferating adventitiou, root and stem tissue.

$3=$ twisting or curvature of elongating internodes.

$4=$ accelerated elongation of internodes.

$5=$ proliferation of axililary buds (young tiller shoots) at base of parent shoot.

$6=$ aberrant emergence of young inner leaves from sheaths of older leaves, i.e., buckling out.

$7=$ twisted and tubular leaves.

$8=$ precocious yellowing of leaves.

$9=$ presence of exceptionally tall leaves due to stimulated leaf elongation.

$10=$ reduced height of shoots due to premature leaf and internode maturation.

$11=$ shoots lodged due to weak and excessively elongated internodes.

$12=$ entire plant dead.

$13=$ vegetative plants expressing no aberrations.

\begin{tabular}{|c|c|c|c|c|c|}
\hline \multicolumn{6}{|c|}{ TREATMENT } \\
\hline Growth regulator applied & $\begin{array}{c}\text { Pellet size } \\
\text { (screen mesh) }\end{array}$ & $\begin{array}{l}\text { Pounds acid } \\
\text { equivalent per } \\
\text { acre applied }\end{array}$ & $\begin{array}{l}\text { Aberration indices } \\
\text { for rice }\end{array}$ & $\begin{array}{l}\text { Number of } \\
\text { plants per } \\
\text { culture* }\end{array}$ & $\begin{array}{l}\text { Average height } \\
\text { of plants } \\
\text { per culture }\end{array}$ \\
\hline Amine 2,4-D & $\begin{array}{l}15 / 30 \\
15 / 30 \\
15 / 30 \\
30 / 60 \\
30 / 60 \\
30 / 60\end{array}$ & $\begin{array}{l}1.5 \\
3.0 \\
6.0 \\
1.5 \\
3.0 \\
6.0\end{array}$ & $\begin{array}{l}1,2,4,7 \\
1,7,10,11 \\
1,2,4,7,10,11 \\
1,2 \\
1,2,4,11 \\
1,2,4,7,10,11\end{array}$ & $\begin{array}{l}16 \\
14 \\
13 \\
21 \\
16 \\
14\end{array}$ & $\begin{array}{c}c m \\
89 \\
78 \\
75 \\
85 \\
91 \\
80\end{array}$ \\
\hline Amine $\mathrm{MCP}$ & $\begin{array}{l}15 / 30 \\
15 / 30 \\
15 / 30 \\
30 / 60 \\
30 / 60 \\
30 / 60\end{array}$ & $\begin{array}{l}1.5 \\
3.0 \\
6.0 \\
1.5 \\
3.0 \\
6.0\end{array}$ & $\begin{array}{l}1,2,4,11 \\
1,2,4 \\
1,2,3,5,10,11 \\
1,2,4 \\
1,2,4,10,11 \\
1,2,4,5,10,11\end{array}$ & $\begin{array}{r}10 \\
17 \\
10 \\
16 \\
12 \\
7\end{array}$ & $\begin{array}{r}92 \\
102 \\
50 \\
101 \\
94 \\
62\end{array}$ \\
\hline Sodium MCP & $\begin{array}{l}15 / 30 \\
15 / 30 \\
15 / 30 \\
30 / 60 \\
30 / 60 \\
30 / 60\end{array}$ & $\begin{array}{l}1.5 \\
3.0 \\
6.0 \\
1.5 \\
3.0 \\
6.0\end{array}$ & $\begin{array}{l}1,2,4,11 \\
1,2,4,5,10,11 \\
1,2,4,10,11 \\
1,2,4,10,11 \\
1,2,4,10,11 \\
1,2,4,10,11\end{array}$ & $\begin{array}{r}12 \\
14 \\
7 \\
10 \\
7 \\
10\end{array}$ & $\begin{array}{r}95 \\
100 \\
70 \\
100 \\
90 \\
95\end{array}$ \\
\hline Potassium MCP & $\begin{array}{l}15 / 30 \\
15 / 30 \\
15 / 30 \\
30 / 60 \\
30 / 60 \\
30 / 60\end{array}$ & $\begin{array}{l}1.5 \\
3.0 \\
6.0 \\
1.5 \\
3.0 \\
6.0\end{array}$ & $\begin{array}{l}1,2,4,11 \\
1,2,4,10,11 \\
1,2,4,5,10,11 \\
1,2,4,5,11 \\
1,2,4,10,11 \\
1,2,4,10,11\end{array}$ & $\begin{array}{r}15 \\
15 \\
9 \\
12 \\
10 \\
10\end{array}$ & $\begin{array}{r}98 \\
101 \\
82 \\
98 \\
92 \\
82\end{array}$ \\
\hline Butyl ester MCP & $\begin{array}{l}15 / 30 \\
15 / 30 \\
15 / 30 \\
30 / 60 \\
30 / 60 \\
30 / 60\end{array}$ & $\begin{array}{l}1.5 \\
3.0 \\
6.0 \\
1.5 \\
3.0 \\
6.0\end{array}$ & $\begin{array}{l}1,2,4,11 \\
1,2,6,10,11 \\
1,2,4,5,6,10,11 \\
1,2,4,11 \\
1,2,4 \\
1,2,4,10,11\end{array}$ & $\begin{array}{l}17 \\
19 \\
15 \\
14 \\
16 \\
12\end{array}$ & $\begin{array}{r}100 \\
95 \\
83 \\
95 \\
95 \\
78\end{array}$ \\
\hline PGBEE 2,4,5-T & $\begin{array}{l}15 / 30 \\
15 / 30 \\
15 / 30 \\
30 / 60 \\
30 / 60 \\
30 / 60\end{array}$ & $\begin{array}{l}1.5 \\
3.0 \\
6.0 \\
1.5 \\
3.0 \\
6.0\end{array}$ & $\begin{array}{l}1,2,4,11 \\
1,2,4,11 \\
1,2,4,11 \\
1,2,4 \\
1,2,4,10,11 \\
1,2,4,10,11\end{array}$ & $\begin{array}{l}18 \\
14 \\
14 \\
15 \\
14 \\
12\end{array}$ & $\begin{array}{l}90 \\
95 \\
98 \\
84 \\
84 \\
77\end{array}$ \\
\hline Control $\nmid \ldots \ldots \ldots \ldots \ldots \ldots$ & $\ldots \ldots$ & $\ldots$ & 13 & 17 & 83 \\
\hline
\end{tabular}

* Initial number of plants per culture varied from 15 to 21 .

$\dagger$ Based upon an average of nine control replicates. 
TABLE 7

FORMULATIONS OF 2,4-D, MCP, AND 2,4,5-T APPLIED AT

CULTURES 31 DAYS AFTER PLANTING

\section{WEE'DS}

$1=$ twisting of petioles and stems; leaves dead and disintegrated at petiole bases (arrowhead).

$2=$ leaves yellow, dying, or dead (arrowhead).

$3=$ stems yellow, dying, or dead (arrowhead).

$4=$ plants eompletely dead (arrowhead).

$5=$ some leaves dead and stems twisted; living leaves and stems, green and actively growing, indicate partial recovery of shoot, development after herbicidal injury (arrowhead).

$6=$ plants uninjured (arrowhead).

$7=$ other aquatic weeds dying or dead (redstem and water plantain).

$8=$ other aquatic weeds injured, followed by partial or complete recovery of shoot and root development (redstem and water plantain).

$9=$ other aquatic weeds uninjured (redstem and water plantain).

\begin{tabular}{|c|c|c|c|c|c|c|}
\hline \multicolumn{7}{|c|}{ RESULTS $\$ \$$} \\
\hline $\begin{array}{l}\text { Dry weight } \\
\text { of shoots } \\
\text { per culturell }\end{array}$ & $\begin{array}{c}\text { Dry weight } \\
\text { per } \\
\text { shoot } \|\end{array}$ & $\begin{array}{c}\text { Number of } \\
\text { panicles } \\
\text { per culture }\end{array}$ & $\begin{array}{l}\text { Number of } \\
\text { panicles per } \\
\text { plant }\end{array}$ & $\begin{array}{l}\text { Dry weight } \\
\text { of panicles } \\
\text { per culture }\end{array}$ & $\begin{array}{c}\text { Dry weight } \\
\text { per } \\
\text { panicle }\end{array}$ & $\begin{array}{c}\text { Aberration } \\
\text { indices } \\
\text { for weeds }\end{array}$ \\
\hline $\begin{array}{c}g m \\
55.2\end{array}$ & $\begin{array}{c}g m \\
3.45\end{array}$ & 19 & 1.19 & $\begin{array}{c}g m \\
18.7\end{array}$ & $\begin{array}{c}g m \\
0.98\end{array}$ & $1,5,7$ \\
\hline 41.7 & 2.98 & 24 & 1.71 & 13.7 & 0.57 & $1,2,4,7$ \\
\hline 38.5 & 2.96 & 17 & 1.31 & 13.4 & 0.79 & 4,7 \\
\hline 66.2 & 3.15 & 21 & 1.00 & 21.2 & 1.01 & $1,5,7$ \\
\hline 53.2 & 3.33 & 18 & 1.12 & 16.2 & 0.90 & $1,5,7$ \\
\hline 37.0 & 2.64 & 18 & 1.29 & 10.8 & 0.60 & $2,3,4,7$ \\
\hline 54.6 & 5.46 & 10 & 1.00 & 21.2 & 2.12 & $1,2,4,7$ \\
\hline 81.2 & 4.78 & 17 & 1.00 & 32.0 & 1.88 & $1,2,4,7$ \\
\hline 9.3 & 0.93 & 3 & 0.30 & 0.9 & 0.30 & $2,4,7$ \\
\hline 64.2 & 4.01 & 16 & 1.00 & 25.6 & 1.60 & 5,7 \\
\hline 54.2 & 4.52 & 11 & 0.92 & 17.3 & 1.57 & $1,2,5,7$ \\
\hline 18.3 & 2.61 & 3 & 0.43 & 1.4 & 0.47 & 4,7 \\
\hline 54.5 & 4.54 & 10 & 0.83 & 21.0 & 2.10 & $1,2,4,7$ \\
\hline 51.0 & 3.64 & 14 & 1.00 & 23.5 & 1.68 & $1,2,4,7$ \\
\hline 10.8 & 1.54 & 3 & 0.43 & 3.0 & 1.00 & 4,7 \\
\hline 44.3 & 4.43 & 9 & 0.90 & 22.0 & 2.44 & $1,2,3,4,7$ \\
\hline 37.3 & 5.33 & 7 & 1.00 & 16.9 & 2.41 & $1,2,3,4,7$ \\
\hline 27.0 & 2.70 & 6 & 0.60 & 11.0 & 1.83 & $1,2,3,4,7$ \\
\hline 59.9 & 3.99 & 17 & 1.13 & 24.4 & 1.44 & $1,4,7$ \\
\hline 53.9 & 3.59 & 14 & 0.93 & 23.4 & 1.67 & $1,2,4,7$ \\
\hline 30.9 & 3.43 & 7 & 0.78 & 11.0 & 1.57 & 4,7 \\
\hline 48.0 & 4.00 & 9 & 0.75 & 19.6 & 2.18 & 4,7 \\
\hline 54.1 & 5. 41 & 10 & 1.00 & 16.3 & 1.63 & $1,4,7$ \\
\hline 40.1 & 4.01 & 9 & 0.90 & 9.6 & 1.07 & 4,7 \\
\hline 71.8 & 4.22 & 17 & 1.00 & 29.6 & 1.74 & $1,2,5,7$ \\
\hline 57.4 & 3.02 & 19 & 1.00 & 21.4 & 1.13 & $1,3,4,7$ \\
\hline 32.5 & 2.17 & 9 & 0.60 & 7.9 & 0.88 & 4,7 \\
\hline 58.8 & 4.20 & 16 & 1.14 & 26.7 & 1.67 & $1,4,7$ \\
\hline 62.0 & 3.88 & 16 & 1.00 & 21.0 & 1.31 & $1,4,7$ \\
\hline 24.9 & 2.08 & 11 & 0.92 & 6.7 & 0.61 & 4,7 \\
\hline 57.7 & 3.21 & 18 & 1.00 & 21.0 & 1.17 & 5,7 \\
\hline 53.7 & 3.84 & 14 & 1.00 & 17.5 & 1.25 & 5,7 \\
\hline 51.9 & 3.71 & 12 & 0.84 & 17.9 & 1.49 & $1,2,3,5,7$ \\
\hline 60.6 & 4.04 & 16 & 1.07 & 15.0 & 0.94 & 5,7 \\
\hline 68.4 & 4.88 & 14 & 1.00 & 17.9 & 1.28 & 5,7 \\
\hline 48.3 & 4.03 & 12 & 1.00 & 10.6 & 0.88 & 5,7 \\
\hline 55.1 & 3.24 & 18 & 1.06 & 10.2 & 0.56 & 6,9 \\
\hline
\end{tabular}

$\ddagger$ Based upon one culture per treatment.

Data were obtained when plants were mature (dry) and harvested (230 days after planting) with the exception of morphologic aberrations. || Shoot includes stems, leaves, and panicles collectively. 
TABLE 8

RESPONSE OF RICE AND SEVERAL AQUATIC WEEDS TO PELLETED SEVERAL DOSAGES TO WATER IN

NoтE: The following is a key to the abberation indices for rice in column 4 and for weeds in the last column.

\section{RICE}

$1=$ excessive numbers of massive adventitious roots at base of shoot.

$2=$ base of shoot swollen due to presence of proliferating adventitious root and stem tissue.

$3=$ twisting or curvature of elongating internodes.

$4=$ accelerated elongation of internodes.

$5=$ proliferation of axillary buds (young tiller shoots) at base of parent shoot.

$6=$ aberrant emergence of young inner leaves from sheaths of older leaves, i.e., buckling out.

$7=$ twisted and tubular leaves.

$8=$ precocious yellowing of leaves.

$9=$ presence of exceptionally tall leaves due to stimulated leaf elongation.

$10=$ reduced height of shoots due to premature leaf and internode maturation.

$11=$ shoots lodged due to weak and excessively elongated internodes.

$12=$ entire plant dead.

$13=$ vegetative plants expressing no aberrations.

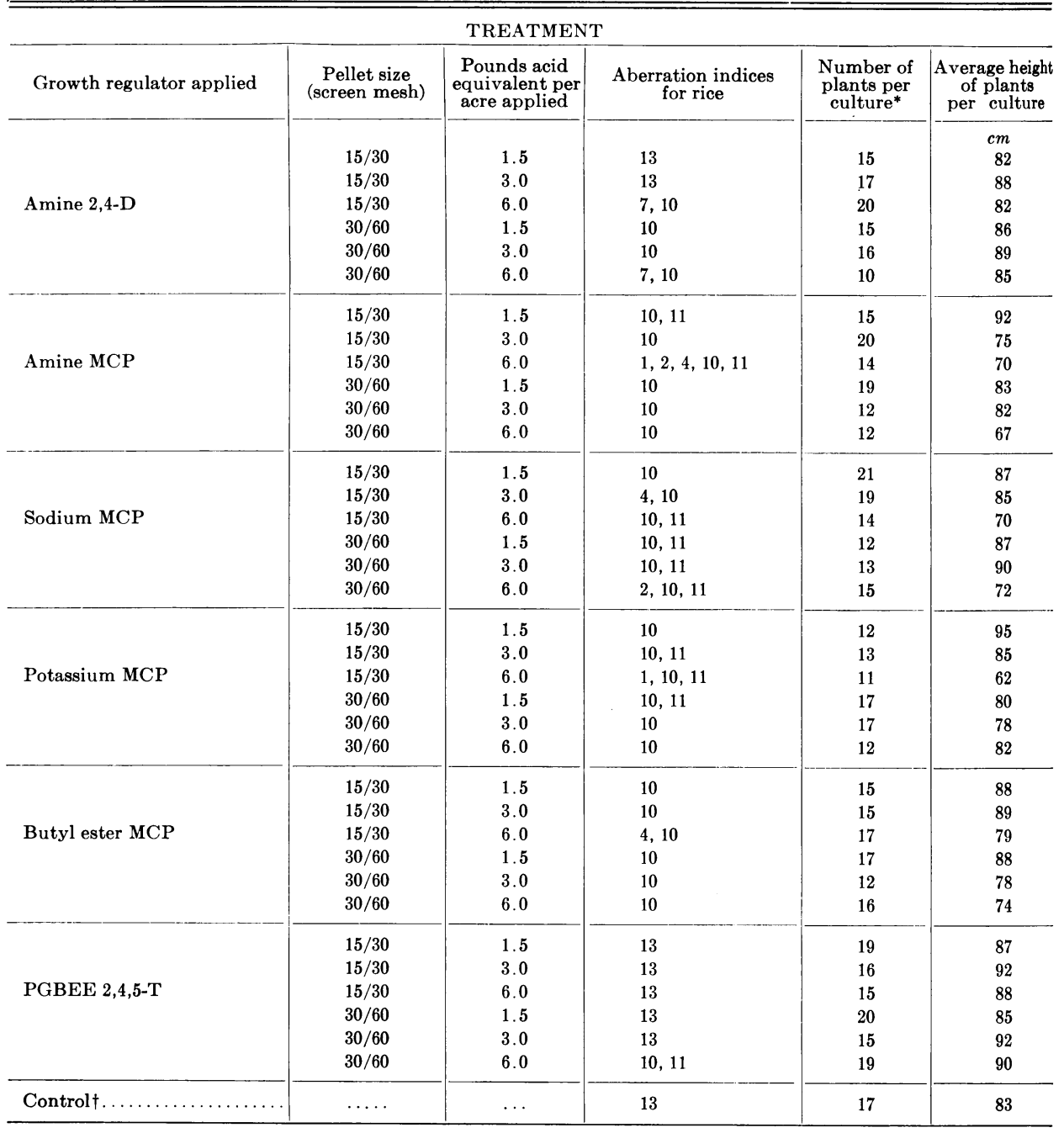

* Initial number of plants per culture varied from 15 to 21 . 
TABLE 8

?ORMULATIONS OF 2,4-D, MCP, AND 2,4,5-T APPLIED AT JULTURES 39 DAYS AFTER PLANTING

\section{WEEDS}

$1=$ twisting of petioles and stems; leaves dead and disintegrated at petiole bases (arrowhead).

2 = leaves yellow, dying, or dead (arrowhead).

3 = stems yellow, dying, or dead (arrowhead).

$4=$ plants completely dead (arrowhead).

$5=$ some leaves dead and stems twisted ; living leaves and stems, green and actively grow-

ing, indicate partial recovery of shoot, development after herbicidal injury (arrowhead).

$6=$ plants uninjured (arrowhead).

$7=$ other aquatic weeds dying or dead (redstem and water plantain).

$8=$ other aquatic weeds injured, followed by partial or complete recovery of shoot and root development (redstem and water plantain).

$9=$ other aquatic weeds uninjured (redstem and water plantain).

\begin{tabular}{|c|c|c|c|c|c|c|}
\hline \multicolumn{7}{|c|}{ RESULTS $\$ 8$} \\
\hline $\begin{array}{l}\text { Dry weight } \\
\text { of shoots } \\
\text { per culture\|l }\end{array}$ & $\begin{array}{c}\text { Dry weight } \\
\text { per } \\
\text { shoot } \|\end{array}$ & $\begin{array}{l}\text { Number of } \\
\text { panicles } \\
\text { per culture }\end{array}$ & $\begin{array}{l}\text { Number of } \\
\text { panicles per } \\
\text { plant }\end{array}$ & $\begin{array}{l}\text { Dry weight } \\
\text { of panicles } \\
\text { per culture }\end{array}$ & $\begin{array}{c}\text { Dry weight } \\
\text { per } \\
\text { panicle }\end{array}$ & $\begin{array}{l}\text { Aberration } \\
\text { indices } \\
\text { for weeds }\end{array}$ \\
\hline $\begin{array}{c}g m \\
64.3\end{array}$ & $\begin{array}{c}g m \\
4.29\end{array}$ & 14 & 0.93 & $\begin{array}{c}g m \\
9.5\end{array}$ & $\begin{array}{c}g m \\
0.68\end{array}$ & $1,2,5,7$ \\
\hline 61.0 & 3.59 & 22 & 1.29 & 10.7 & 0.49 & $1,5,7$ \\
\hline 50.7 & 2.54 & 22 & 1.10 & 14.9 & 0.68 & 4,7 \\
\hline 59.6 & 3.97 & 17 & 1.13 & 10.8 & 0.63 & 5,7 \\
\hline 60.2 & 3.76 & 17 & 1.06 & 14.0 & 0.82 & $1,4,7$ \\
\hline 47.3 & 4.73 & 12 & 1.20 & 9.4 & 0.78 & $1,2,4,7$ \\
\hline 62.8 & 4.19 & 15 & 1.00 & 24.7 & 1.65 & $1,2,3,4,7$ \\
\hline 58.5 & 2.93 & 19 & 0.85 & 17.2 & 0.91 & $1,2,3,4,7$ \\
\hline 42.0 & 3.00 & 12 & 0.86 & 12.2 & 1.02 & $1,4,7$ \\
\hline 51.2 & 2.69 & 18 & 0.95 & 18.9 & 1.05 & $1,4,7$ \\
\hline 48.2 & 4.02 & 11 & 0.92 & 12.2 & 1.11 & $1,4,7$ \\
\hline 20.0 & 1.67 & 8 & 0.67 & 6.3 & 0.79 & $1,2,4,7$ \\
\hline 61.7 & 2.94 & 21 & 1.00 & 20.8 & 0.99 & $1,5,7$ \\
\hline 54.4 & 2.86 & 24 & 1.26 & 16.3 & 0.68 & $1,2,3,4,7$ \\
\hline 31.1 & 2.22 & 13 & 0.93 & 8.3 & 0.64 & $1,2,4,7$ \\
\hline 49.3 & 4.11 & 12 & 1.00 & 19.2 & 1.60 & $1,5,7$ \\
\hline 44.0 & 3.39 & 13 & 1.00 & 12.5 & 0.96 & $1,4,7$ \\
\hline 27.9 & 1.86 & 9 & 0.60 & 4.7 & 0.52 & $1,2,3,4,7$ \\
\hline 48.3 & 4.03 & 10 & 0.84 & 18.8 & 1.88 & $1,2,4,7$ \\
\hline 56.6 & 4.35 & 13 & 1.00 & 14.1 & 1.08 & $1,2,4,7$ \\
\hline 18.7 & 1.70 & 6 & 0.55 & 4.7 & 0.78 & 4,7 \\
\hline 51.5 & 3.03 & 16 & 0.94 & 18.0 & 1.13 & $1,2,4,7$ \\
\hline 50.9 & 2.99 & 15 & 0.88 & 8.1 & 0.54 & $1,2,4,7$ \\
\hline 40.2 & 4.45 & 8 & 0.67 & 11.4 & 1.43 & $1,2,3,4,7$ \\
\hline 69.6 & 4.64 & 18 & 1.20 & 16.2 & 0.90 & $1,5,7$ \\
\hline 62.3 & 4.15 & 15 & 1.00 & 18.4 & 1.23 & $1,2,4,7$ \\
\hline 47.8 & 2.81 & 13 & 0.76 & 13.6 & 1.05 & $1,4,7$ \\
\hline 61.7 & 3.63 & 13 & 0.76 & 17.9 & 1.38 & $1,4,7$ \\
\hline 35.8 & 2.98 & 12 & 1.00 & 10.9 & 0.91 & $1,5,7$ \\
\hline 43.5 & 2.72 & 16 & 1.00 & 8.6 & 0.54 & $1,2,4,7$ \\
\hline 48.3 & 2.54 & 19 & 1.00 & 18.1 & 0.95 & $1,5,7$ \\
\hline 53.4 & 3.34 & 15 & 0.94 & 16.0 & 1.07 & $1,5,7$ \\
\hline 47.9 & 3.19 & 16 & 1.00 & 15.0 & 0.94 & $1,5,7$ \\
\hline 58.3 & 2.92 & 19 & 0.95 & 19.9 & 1.05 & 5,7 \\
\hline 61.8 & 4.12 & 14 & 0.93 & 12.6 & 0.90 & $1,5,7$ \\
\hline 56.5 & 2.97 & 19 & 1.00 & 16.4 & 0.86 & $1,5,7$ \\
\hline 55.1 & 3.24 & 18 & 1.06 & 10.2 & 0.56 & 6,9 \\
\hline
\end{tabular}

$\ddagger$ Based upon one culture per treatment.

Data were obtained when plants were mature (dry) and harvested (230 days after planting) with the exception of morphologic aberrations.

|| Shoot includes stems, leaves, and panicles collectively. 
Noтt: The following is a key to the abberation indices for rice in column 4 and for weeds in the last column.

\section{RICE}

$1=$ excessive numbers of massive adventitious roots at base of shoot.

$2=$ base of shoot swollen due to presence of proliferating adventitious root and stem tissue.

$3=$ twisting or curvature of elongating internodes.

$4=$ accelerated elongation of internodes.

$5=$ proliferation of axillary buds (young tiller shoots) at base of parent shoot.

$6=$ aberrant emergence of young inner leaves from sheaths of older leaves, i.e., buckling out.

$7=$ twisted and tubular leaves.

$8=$ precocious yellowing of leaves.

$9=$ presence of exceptionally tall leaves due to stimulated leaf elongation.

$10=$ reduced height of shoots due to premature leaf and internode maturation.

$11=$ shoots lodged due to weak and excessively elongated internodes.

$12=$ entire plant dead.

$13=$ vegetative plants expressing no aberrations.

\begin{tabular}{|c|c|c|c|c|c|}
\hline \multicolumn{6}{|c|}{ TREATMENT } \\
\hline Growth regulator applied & $\begin{array}{c}\text { Pellet size } \\
\text { (screen mesh) }\end{array}$ & $\begin{array}{l}\text { Pounds acid } \\
\text { equivalent per } \\
\text { acre applied }\end{array}$ & $\begin{array}{l}\text { Aberration indices } \\
\text { for rice }\end{array}$ & $\begin{array}{l}\text { Number of } \\
\text { plants per } \\
\text { culture* }\end{array}$ & $\begin{array}{c}\text { Average height } \\
\text { of plants } \\
\text { per culture }\end{array}$ \\
\hline Amine $2,4-\mathrm{D}$ & $\begin{array}{l}15 / 30 \\
15 / 30 \\
15 / 30\end{array}$ & $\begin{array}{l}1.5 \\
3.0 \\
6.0\end{array}$ & $\begin{array}{l}10 \\
10 \\
10\end{array}$ & $\begin{array}{l}19 \\
20 \\
19\end{array}$ & $\begin{array}{r}c m \\
84 \\
95 \\
89\end{array}$ \\
\hline Amine $\mathrm{MCP}$ & $\begin{array}{l}15 / 30 \\
15 / 30 \\
15 / 30\end{array}$ & $\begin{array}{l}1.5 \\
3.0 \\
6.0\end{array}$ & $\begin{array}{l}10 \\
10 \\
10\end{array}$ & $\begin{array}{l}17 \\
15 \\
18\end{array}$ & $\begin{array}{l}88 \\
85 \\
78\end{array}$ \\
\hline Sodium MCP & $\begin{array}{l}15 / 30 \\
15 / 30 \\
15 / 30\end{array}$ & $\begin{array}{l}1.5 \\
3.0 \\
6.0\end{array}$ & $\begin{array}{l}13 \\
13 \\
10\end{array}$ & $\begin{array}{l}17 \\
23 \\
18\end{array}$ & $\begin{array}{l}86 \\
95 \\
75\end{array}$ \\
\hline Potassium MCP & $\begin{array}{l}15 / 30 \\
15 / 30 \\
15 / 30\end{array}$ & $\begin{array}{l}1.5 \\
3.0 \\
6.0\end{array}$ & $\begin{array}{l}13 \\
13 \\
10\end{array}$ & $\begin{array}{l}21 \\
16 \\
15\end{array}$ & $\begin{array}{l}82 \\
87 \\
83\end{array}$ \\
\hline Butyl ester MCP & $\begin{array}{l}15 / 30 \\
15 / 30 \\
15 / 30\end{array}$ & $\begin{array}{l}1.5 \\
3.0 \\
6.0\end{array}$ & $\begin{array}{l}10 \\
10 \\
10\end{array}$ & $\begin{array}{l}21 \\
15 \\
19\end{array}$ & $\begin{array}{l}87 \\
97 \\
76\end{array}$ \\
\hline PGBEE 2,4,5-T & $\begin{array}{l}15 / 30 \\
15 / 30 \\
15 / 30\end{array}$ & $\begin{array}{l}1.5 \\
3.0 \\
6.0\end{array}$ & $\begin{array}{l}13 \\
13 \\
10\end{array}$ & $\begin{array}{r}23 \\
19 \\
8\end{array}$ & $\begin{array}{l}88 \\
89 \\
75\end{array}$ \\
\hline Control $\nmid \ldots \ldots \ldots \ldots \ldots$ & $\ldots \ldots$ & $\ldots$ & 13 & 17 & 83 \\
\hline
\end{tabular}

* Initial number of plants per culture varied from 15 to 21 .

$\dagger$ Based upon an average of nine control replicates. 
TABLE 9

FORMULATIONS OF 2,4-D, MCP, AND 2,4,5-T APPLIED AT CULTURES 60 DAYS AFTER PLANTING

\section{WEEDS}

$1=$ twisting of petioles and stems; leaves dead and disintegrated at petiole bases (arrowhead).

$2=$ leaves yellow, dying, or dead (arrowhead).

3 = stems yellow, dying, or dead (arrowhead).

$4=$ plants completely dead (arrowhead).

5 = some leaves dead and stems twisted; living leaves and stems, green and actively grow-

ing, indicate partial recovery of shoot, development after herbicidal injury (arrowhead).

$6=$ plants uninjured (arrowhead).

$7=$ other aquatic weeds dying or dead (redstem and water plantain).

$S=$ other aquatic weeds injured, followed by partial or complete recovery of shoot and root development (redstem and water plantain).

$9=$ other aquatic weeds uninjured (redstem and water plantain).

\begin{tabular}{|c|c|c|c|c|c|c|}
\hline \multicolumn{7}{|c|}{ RESULTS $+\S$} \\
\hline $\begin{array}{l}\text { Dry weight } \\
\text { of shoots } \\
\text { per culturell }\end{array}$ & $\begin{array}{c}\text { Dry weight } \\
\text { per } \\
\text { shoot } \|\end{array}$ & $\begin{array}{l}\text { Number of } \\
\text { panicles } \\
\text { per culture }\end{array}$ & $\begin{array}{c}\text { Number of } \\
\text { panicles per } \\
\text { plant }\end{array}$ & $\begin{array}{l}\text { Dry weight } \\
\text { of panicles } \\
\text { per culture }\end{array}$ & $\begin{array}{c}\text { Dry weight } \\
\text { per } \\
\text { panicle }\end{array}$ & $\begin{array}{l}\text { Aberration } \\
\text { indices } \\
\text { for weeds }\end{array}$ \\
\hline$\underset{73}{g m}$ & $\underset{g m}{g m}$ & 20 & 105 & $\stackrel{g m}{g m}$ & $g m$ & 48 \\
\hline $\begin{array}{l}73.8 \\
60.0\end{array}$ & $\begin{array}{l}3.88 \\
3.00\end{array}$ & 19 & $\begin{array}{l}1.05 \\
0.95\end{array}$ & $\begin{array}{l}13.5 \\
10.3\end{array}$ & $\begin{array}{l}0.68 \\
0.54\end{array}$ & 5,7 \\
\hline 51.1 & 2.69 & 22 & 1.16 & 9.6 & 0.44 & 4,7 \\
\hline 52.3 & 3.08 & 12 & 0.71 & 10.4 & 0.87 & 5,7 \\
\hline 52.1 & 3.47 & 15 & 1.00 & 8.6 & 0.51 & 4,7 \\
\hline 43.8 & 2.43 & 11 & 0.61 & 4.4 & 0.40 & 4,7 \\
\hline 55.1 & 3.24 & 19 & 1.12 & 4.9 & 0.26 & 5,7 \\
\hline 70.7 & 3.07 & 19 & 0.83 & 16.7 & 0.88 & 4,7 \\
\hline 38.2 & 2.12 & 7 & 0.39 & 4.2 & 0.60 & 4,7 \\
\hline 59.8 & 2.86 & 19 & 0.90 & 10.0 & 0.53 & 5,7 \\
\hline 61.5 & 3.84 & 23 & 1.44 & 12.3 & 0.53 & 4,7 \\
\hline 42.6 & 2.84 & 15 & 1.00 & 11.7 & 0.78 & 4,7 \\
\hline 59.1 & 2.81 & 23 & 1.09 & 12.6 & 0.55 & 5,7 \\
\hline 59.8 & 3.99 & 15 & 1.00 & 17.3 & 1.15 & 4,7 \\
\hline 57.2 & 3.01 & 11 & 0.58 & 6.2 & 0.56 & 4,7 \\
\hline 72.0 & 3.13 & 25 & 1.09 & 10.7 & 0.43 & 5.7 \\
\hline 59.7 & 3.14 & 20 & 1.05 & 14.2 & 0.71 & 5.7 \\
\hline 40.8 & 5.10 & 9 & 1.13 & 6.7 & 0.74 & 5,7 \\
\hline 55.1 & 3.24 & 18 & 1.06 & 10.2 & 0.56 & 6,9 \\
\hline
\end{tabular}

$\ddagger$ Based upon one culture per treatment.

Data were obtained when plants were mature (dry) and harvested (230 days after planting) with the exception of morphologic aberrations.

I Shoot includes stems, leaves, and panicles collectively. 
$4 m-4, ' 56$ ( B3169) L.L.

$1+1$ 
The journal Hilgardia is published at irregular intervals, in volumes of about 600 pages. The number of issues per volume varies.

Subscriptions are not sold. The periodical is sent as published only to libraries, or to institutions in foreign countries having publications to offer in exchange.

You may obtain a single copy of any issue free, as long as the supply lasts; please request by volume and issue number from:

\section{Agricultural Publications \\ Room 22, Giannini Hall \\ University of California \\ Berkeley 千, California}

The limit to nonresidents of California is 10 separate issues on a single order. A list of the issues still available will be sent on recuest.

In our publications it is sometimes convenient to use trade names of products or equipment rather than scientific identifications. In so doing it is unavoidable in some cases that similar products which are on the market under other trade names may not be cited. No endorsement of named products is intended nor is criticism implied of similar products which are not mentioned. 


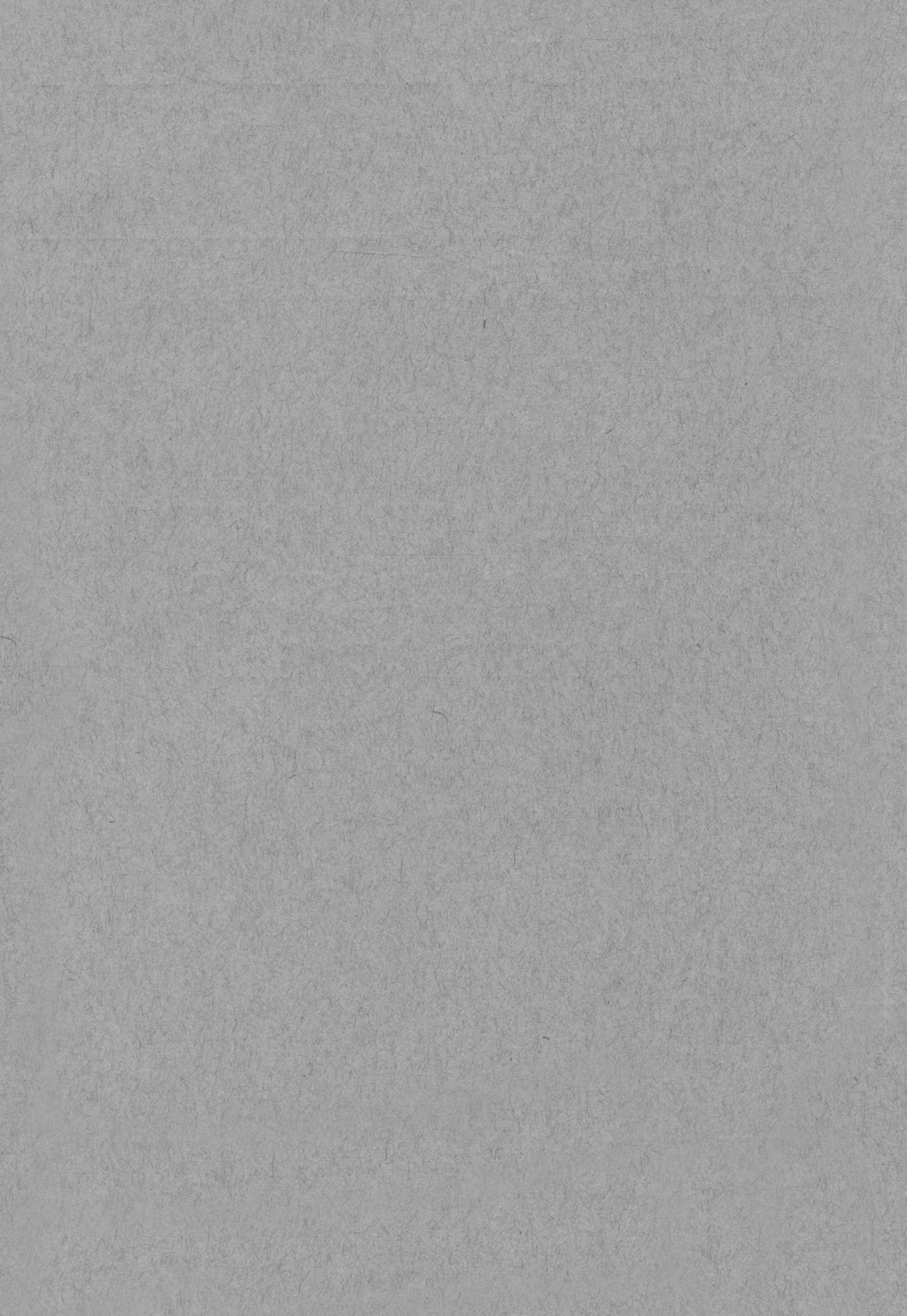

